\title{
What Is the Evidence that Parkinson's Disease Is a Prion Disorder, Which Originates in the Gut?
}

\author{
Małgorzata Kujawska * (iD and Jadwiga Jodynis-Liebert \\ Department of Toxicology, Poznan University of Medical Sciences, 30 Dojazd Str., 60-631 Poznań, Poland; \\ liebert@ump.edu.pl \\ * Correspondence: kujawska@ump.edu.pl; Tel.: +48-61-847-20-81 (ext. 156)
}

Received: 3 October 2018; Accepted: 9 November 2018; Published: 12 November 2018

\begin{abstract}
Parkinson's disease (PD) is a neurodegenerative disorder resulting from degeneration of dopaminergic neurons in the substantia nigra pars compacta (SNpc). PD is characterized by motor dysfunctions as well as gastrointestinal symptoms and mental impairment. The pathological hallmark of PD is an accumulation of misfolded $\alpha$-synuclein aggregates within the brain. The etiology of $\mathrm{PD}$ and related synucleinopathy is poorly understood, but recently, the hypothesis that $\alpha$-synuclein pathology spreads in a prion-like fashion originating in the gut has gained much scientific attention. A crucial clue was the appearance of constipation before the onset of motor symptoms, gut dysbiosis and synucleinopathy in PD patients. Another line of evidence, demonstrating accumulation of $\alpha$-synuclein within the peripheral autonomic nervous system (PANS), including the enteric nervous system (ENS), and the dorsal motor nucleus of the vagus (DMV) support the concept that $\alpha$-synuclein can spread from the ENS to the brain by the vagus nerve. The decreased risk of PD following truncal vagotomy supports this. The convincing evidence of the prion-like behavior of $\alpha$-synuclein came from postmortem observations that pathological $\alpha$-synuclein inclusions appeared in healthy grafted neurons. In this review, we summarize the available data from human subjects' research and animal experiments, which seem to be the most suggestive for explaining the hypotheses.
\end{abstract}

Keywords: enteric nervous system; dysbiosis; Braak's staging system

\section{Introduction}

Parkinson's disease (PD) is a chronic human neurodegenerative disorder, which is characterized by motor dysfunction including tremors, bradykinesia, rigidity and postural instability. The neuropathology of the symptoms is associated with a severe loss of dopaminergic (DAergic) neurons in the substantia nigra pars compacta (SNpc) and progressive accumulation of Lewy pathology (LP) in the form of Lewy bodies (LBs) and Lewy neurites (LNs), mainly composed of misfolded $\alpha$-synuclein [1].

In addition to the motor symptomatology, nonmotor manifestations such as gastrointestinal dysfunction, including constipation, delayed gastric emptying, hypersalivation, dysphagia and nausea as well as olfactory impairment, depression, and sleep disturbances appear throughout disease stages in PD. It has been reported that the nonmotor symptoms, mainly constipation and olfactory deficit, predate the motor ones, sometimes by up to ten years [2].

A growing body of evidence highlights the relevance of constipation, with prevalence in PD patients ranging from $24.6 \%$ to $63.0 \%$; to be not only the symptom but also to play a crucial role in the development of pathophysiological changes underlying motor impairment [3]. The slow colonic motility depending on intrinsic circuits in the enteric nervous system (ENS) appears to be the primary cause of the anomaly in gut functionality in PD. The ENS consists of two plexuses, myenteric (or Auerbach's plexus) and submucosal (or Meissner plexus) located within the walls of the gut and controls gastrointestinal function independently from the central nervous system 
(CNS) [4]. Braak et al. [5] based on their neuropathological findings have suggested that the earliest neuropathological features of PD occur in the ENS, olfactory bulbs, and lower brainstem, with particular reference to the dorsal motor nucleus of the vagus (DMV). Furthermore, a pathological hallmark of the disease, LBs, in the olfactory epithelium [6] and in both submucosal and mucosal plexuses of the gut, from the oesophagus to the rectal end in PD patients, has been reported to reflect the preclinical stage of PD [7,8]. Braak and Tredici [9] have formulated the hypothesis that the abnormal $\alpha$-synuclein deposition begins in the olfactory bulbs and/or in the ENS, due to the action of an environmental agent or pathogen, and then proceeds towards the SNpc and further sites in the CNS.

Based on the above it is suggested that in the very early stages of PD, the first event of $\alpha$-synuclein misfolding occurs in the ENS and then spreads transneuronally in a prion-like fashion through the gut-brain ascending pathways to the CNS and finally causes the degeneration of DAergic neurons in the SNpc.

\section{The Hypothesis of Prion-Like Propagation of A-Synuclein within the Gut-Brain Axis}

Prion stands for 'proteinaceous infectious particle' which can self-transform its shape and propagate and thus can be transmitted from cell-to-cell, between individuals and even different species. Emerging evidence suggests that misfolded $\alpha$-synuclein behaves in a prion-like fashion, underlying its intercellular transfer and interregional transport, that contributes to the neuropathology of Parkinson's disease. Of note, epidemiological studies conducted so far do not support the hypothesis that $\alpha$-synucleinopathy might be communicable [10].

A starting point of the hypothesis came from independent postmortem observations that embryonic mesencephalic "healthy" neurons grafted into the brains of PD patients acquired LBs several years after the transplantation [11-13]. Numerous in vitro experiments have demonstrated that cultured neurons can both secrete and take $\alpha$-synuclein up from the extracellular environment, which supports the idea of its transcellular transmission in a prion-like manner [14-16]. Based on the results of the studies, a hypothetical model of $\alpha$-synuclein cell-to-cell transmission has been developed that assumes a prion-like mechanism, by which native protein with $\alpha$-helical structure adopts a toxic form with a $\beta$-sheet structure, triggering the misfolding of further native protein in a self-perpetuating process [17]. Thereby, the abnormal protein acts as a seed or template for misfolding normal $\alpha$-synuclein. However, whether the seeds are constantly formed and actively removed throughout life, or their formation is rather a rare event initiating disease, is still unsolved. The stabilized $\beta$-sheet conformations aggregate in neurons into toxic assemblies composed of fibrillar, phosphorylated and ubiquitinated $\alpha$-synuclein-the main component of LBs and LNs. The export of intraneuronal $\alpha$-synuclein assemblies into the extracellular space and then its uptake by neighboring neurons or astrocytes are crucial for the prion hypothesis of PD. It is suggested that neurons containing LBs could release amyloid aggregates and seeds them into the extracellular milieu by non-classical exocytosis, in which aberrant $\alpha$-synuclein is targeted by a ubiquitin-specific protease or via exosomes, as well as after cell injury or death. Exosomes, microvesicles and tunneling nanotubes (TNTs) are proposed, in turn, to participate in the transfer of $\alpha$-synuclein from one cell to another. The extracellular $\alpha$-synuclein can then undergo internalization by endocytosis through either neighbor neurons or glial cells. The uptake of exogenous seeds directly promotes the conversion of $\alpha$-synuclein monomers in the recipient cell into aggregates and fibrils, and new LBs are formed as a result $[18,19]$. Besides the mentioned above TNTs several other biomolecules, such as the ubiquitin-specific protease 19, heat shock protein 70, and lymphocyte-activation gene 3 (LAG3) are suggested to be involved in the prion-like spread of $\alpha$-synuclein [20]. It should be noted that cross-sectional histopathological examinations have revealed that proteinaceous lesions appear and spread in disease-specific spatiotemporal patterns [19].

The gut-brain axis model facilitates a bidirectional network communication through biochemical signaling between the ENS and CNS [21]. This model has been reported to comprise the CNS, 
the neuroimmune and neuroendocrine systems, the parasympathetic and sympathetic sections of the autonomic nervous system and the gut microbiota [22]. In the context of Parkinson's disease, a putative role of intestinal microbiota in regulating the gut-brain axis has recently been evoked. Several pathways have been demonstrated to be involved in the gut microbiota-brain communication, including neural connections (vagus nerve), neuroactive mediators produced by commensals bacteria during their metabolism, mainly short chain fatty acids (SCFAs), proinflammatory cytokines, and tryptophan metabolism as well as the effects of intestinal microbiota on gut function, metabolism, and immune system of the host $[23,24]$. Results from experiments on animals have suggested that $\alpha$-synuclein can spread from the ENS to the brain by the vagus nerve [25-27]. The hypothesis is supported by the data about the decreased risk of developing PD in patients who underwent a full truncal vagotomy [28]. Research on the intestinal tissue of PD patients has revealed the altered concentrations of SCAFs [29] as well as increased intestinal permeability [30] that correlates with changes in colonic microbiota. In addition, analysis of mucosal biopsies and faecal samples provides evidence that the first event of $\alpha$-synuclein misfolding in the gastrointestinal (GI) tract does not necessarily need a pathogenic or environmental stimulus since proinflammatory dysbiosis present in the gut of PD patients could trigger inflammation-induced $\alpha$-synucleinopathy and the development of PD pathology [31].

The scientific community is becoming increasingly aware of the importance of the hypothesis that the $\alpha$-synuclein aggregation spreads via a prion-like mechanism originating in the gut. Searching PubMed for references for this review has revealed a steadily increasing number of articles devoted to this topic (Figure 1). The present review is intended to provide a comprehensive overview of current human and experimental evidence on the hypothesis that $\alpha$-synuclein may be transmitted in a prion-like manner within the gut-brain axis.

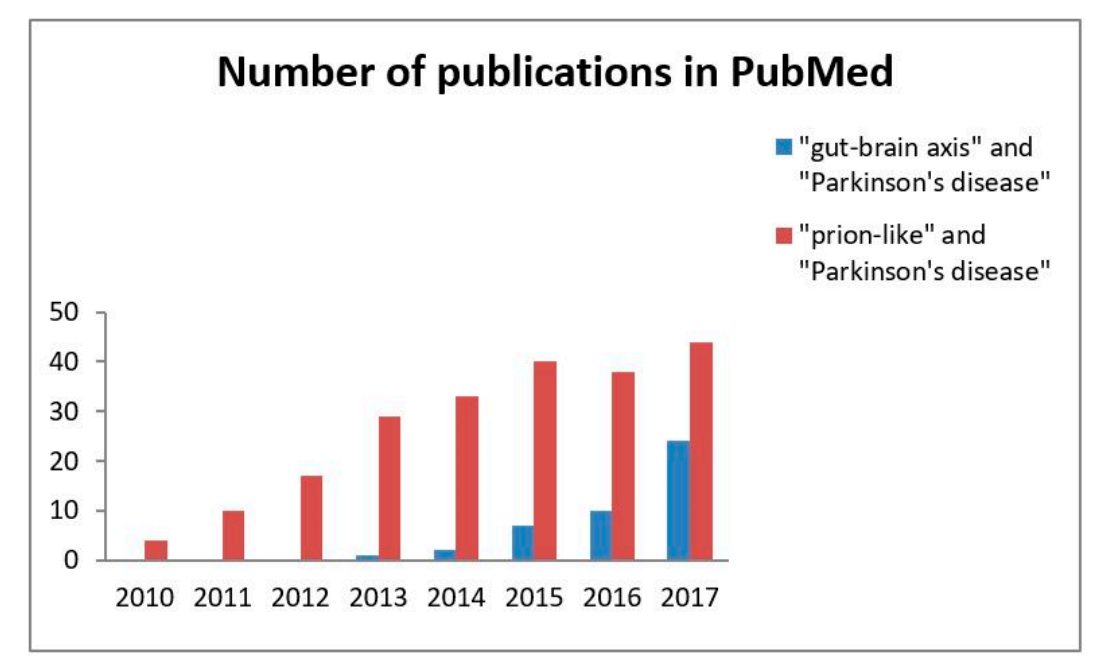

Figure 1. A number of publications on the concept of the gut-brain axis and $\alpha$-synuclein as a prion-like protein in Parkinson's disease. The search was performed for each entire year (2010-2017). The values are the crude total number of articles published in English per year according to PubMed.

\section{Evidence in PD Patients}

Over the last decade, the connection between the intestinal environment and the CNS has attracted the interest of researchers with a great emphasis on the role of intestinal microbiota in regulating the gut-brain axis [20,24,32]. Given the evidence in human subjects, summarized in Table 1, it is quite likely that gut microbes contribute to the pathogenesis of PD. In this section, we focus on the potential of intestinal health impairments to the development of the neurodegenerative condition.

Recent studies on the gut microbiota have demonstrated gut dysbiosis [29-31,33-38] and/or small intestinal overgrowth (SIBO) [39-42] in PD patients, which correlated well with the severity of motor dysfunction $[34,39,40]$ or with the GI impairment, such as constipation $[33,34]$, bloating and flatulence [39], increased gut permeability [30,33] and inflammation [30]. A systematic review by 
Gerhardt and Mohajeri [43] have summarized the findings on the composition of fecal or intestinal bacteria populations in PD patients published between 1 January 2013 and 31 December 2017 showing an increase in Lactobacillus, Bifidobacterium, Verrucomicrobiaceae, and Akkermansia and a decrease in Faecalibacterium spp., Coprococcus spp., Blautia spp., Prevotella spp. and Prevotellaceae.

Since enteric bacteria possess the capacity to produce various neuroactive molecules, such as serotonin, catecholamines, glutamate, gamma-aminobutyric acid (GABA) and SCFAs interacting with the intrinsic enteric neurons of the ENS and extrinsic afferent neurons of the CNS, it has been hypothesized that they are able to influence GI motility as well as CNS functions [44]. Intestinal microbes are the source of SCFAs such as acetic acid, propionic acid, and butyric acid, which are produced during the fermentation process. These molecules, in particular butyrate, are known to play an important role in maintaining the colonic epithelium integrity through the regulation of tight junction proteins, including zona occludens proteins and occludin [45]. Importantly, the decreased expression of occludin has been demonstrated in colonic samples from PD patients, in which LP in the submucosa has been detected [46]. The increased permeability has been demonstrated to enable translocation of bacteria and endotoxin, subsequently to trigger an inflammatory cascade leading to local and/or systemic inflammation as a consequence [45]. Moreover, the gut-derived inflammation has been suggested to be involved in PD pathology [32,47]. On the other hand, butyric acid was reported to have also a beneficial effect against constipation by increasing peristaltic efficiency and limiting the active secretion of water, sodium, and chloride ions by the intestinal epithelial cells [48] as well as due to its anti-inflammatory activity [49]. Of note, the depletion of SCFA and SCFA-producing organisms has been observed in PD patients [29] and in other synucleinopathy conditions such as multiple system atrophy [50]. Supporting this, the enhanced inflammation, as a consequence of alterations in the immune response to both commensal and harmful bacteria, has been suggested to induce LP, since a significant association between some polymorphisms in peptidoglycan recognition protein-encoding genes and an increased risk of developing PD has been demonstrated [51].

Another analysis of microbiota composition in PD pointed to differences in microbiota metabolism, namely in $\beta$-glucuronate and tryptophan degrading pathways [36,37]. This is in line with previous research findings demonstrating an increased level of tryptophan metabolites including kynurenine (KYN), xanthurenic acid, and hydroxyanthranilic acid in the urine of idiopathic PD patients, compared with that of controls [52]. The increased tryptophan metabolism is of particular interest, as it is a precursor of serotonin and is decreased in PD patients' brains. In addition, tryptophan catabolites, notably KYN, have been reported to disrupt epithelial barrier integrity and induce inflammation in the intestine as well as could be a source of systemic neuropathology [53]. Keshavarzian et al. [31] have demonstrated a reduction in normal metabolic pathways and an increase of metabolic activities devoted to lipopolysaccharide biosynthesis and type III bacterial secretion systems. Supporting this, Tetz et al. [38] based on a detailed comparative metagenomic analysis of intestinal phagobiota in PD patients and non-parkinsonian individuals, have identified shifts of the phage/bacteria ratio in lactic acid bacteria, producing dopamine and regulating intestinal permeability, which are major factors implicated in PD pathogenesis. These findings seem to support the concept of gut-originating and inflammation-driven PD pathogenesis. Interestingly, Forsyth and co-workers [30] have demonstrated that the changes in bacterial population composition and increased intestinal permeability positively correlated with the increased level of intestinal $\alpha$-synuclein in PD patients. The positive feedback loop involving the gut inflammation in conjunction with the expression of $\alpha$-synuclein in the enteric neurites of the upper GI tract has also been demonstrated in pediatric patients, who suffer from acute and chronic inflammation in the intestinal wall [54].

Another intestinal feature of PD widely reported is the presence of enteric abnormalities in $\alpha$-synuclein, which is expressed as a normal component of the ENS [55]. Numerous pathological studies indicate, however, that the occurrence of $\alpha$-synuclein in the intestine of PD patients is more expressed than in age-matched healthy controls [30,56-60]. Of note, the increased $\alpha$-synuclein 
immunoreactivity has also been demonstrated in intestinal biopsies collected from clinically healthy individuals, who later experienced an onset of PD [57,59]. It is reasonable to speculate that $\alpha$-synuclein pathology is present before CNS neurodegeneration, as an over-expression of $\alpha$-synuclein correlates positively with the prevalence of its aggregations in both the intestines and brains. In line with this, $\alpha$-synuclein inclusions have been almost consistently shown to occur in the GI tract of PD patients in all stages of the disorder [61-63]. Phosphorylated and aggregated $\alpha$-synuclein has been detected in the esophagus, stomach, small intestine, colon, and rectum of PD patients [64-68]. Some authors have also reported the presence of LBs and/or LNs in GI tissue samples $[7,46,55,62]$. The accumulation of LP has been demonstrated to be present in the peripheral autonomic nervous system (PANS), including the ENS and autonomic ganglia $[7,55,69,70]$. There are studies showing the presence of a rostrocaudal gradient of $\alpha$-synuclein within the GI tract $[65,70]$ with the highest frequency of prevalence in the submandibular gland and lower esophagus, followed by the stomach, small bowel, colon and rectum [71]. Of note, this gradient coincides with the distribution of vagal innervation from the DMV [71], which has been shown to be also affected in PD [69,72-74]. In addition, the involvement of spinal and peripheral sympathetic and parasympathetic neurons by $\alpha$-synuclein pathology has been reported $[65,69,75]$.

The involvement of the synucleinopathy of a central or peripheral autonomic system likely reflects the pathophysiology of gastrointestinal symptoms in PD patients since it controls motility and secretion in GI. Constipation and impaired defecatory function may reflect $\alpha$-synuclein pathology in myenteric and submucosal neurons, which were almost constantly affected in PD $[56,61,62,64,70,76]$. Lebouvier et al. [61] have reported a correlation between the burden of $\alpha$-synuclein inclusions in the submucosal plexus in biopsies of the ascending colon and the presence of chronic constipation [61]. Upper gastrointestinal motility is primarily controlled by the DMV. Therefore, esophageal and gastric dysmotility may be associated with affected by $\alpha$-synuclein pathology DMV, which was shown in PD patients [69,72-74]. Several studies showing the presence of $\alpha$-synuclein inclusions in salivary glands and the submandibular gland $[65,67,77,78]$ have suggested its involvement in the impairment of salivary function in PD. In addition, the presence of LP in the neurons of the olfactory system of PD patients has been reported $[74,79,80]$ to be likely involved in the loss of smell observed in the early stage of the disease [81].

Pathological investigations have revealed a specific chronological and regional pattern during the progression of $\mathrm{PD}$, on the basis of which Braak and colleagues developed a pathological staging system $[5,82,83]$. At this time, the pathogenesis of PD remains poorly understood. Nonetheless, there is considerable evidence that the olfactory bulb, the ENS, the intermediolateral nucleus of the spinal cord and the dorsal motor nucleus of the vagus are the sites of early involvement $[69,75,82,84]$. This concept also presents a potential explanation as to why the majority of PD patients exhibit the early and severely affected DMV and the olfactory bulb [85]. Therefore, the 'dual-hit hypothesis' postulates that $\alpha$-synuclein pathology might initially be triggered by exogenous insults targeting the gut and olfactory system. Its anterograde progress from the olfactory system into the temporal lobe, and the retrograde transport to the brainstem from the gut, seems to likely reflect the observed symptoms in a subgroup of PD patients with young-onset and long duration of disease [86]. This scenario reflects the direct contact between environmental agents and neurons of the olfactory bulb and ENS through inhalation or ingestion, respectively, and the prion-like transfer of the abnormal $\alpha$-synuclein along preganglionic parasympathetic fibres to the DMV. Supporting this, Gray and collaborators [87], who have revealed the relative abundance of $\alpha$-synuclein within macrophages in the vermiform appendix in patients with no history of neurological disease, suggested this anatomical locus as a candidate for the initiation of the "prion-like" cascade in PD pathogenesis.

The concept that the vagal nerve constitutes a major highway for spreading of $\alpha$-synuclein pathology into the CNS is supported by epidemiological studies on a large scale, showing that vagotomy could be protective against PD. Two independent studies have reported that the risk of PD may be substantially decreased following truncal vagotomy $[28,88]$. Finally, some evidence supports 
the scenario that synucleinopathy spreads in prion-like fashion into the brain in a human subject. This concept presents a potential explanation as to why Lewy bodies were present, at autopsy, in the grafted neurons of fetal midbrain tissue in the striatum of Parkinson's disease patients 1-2 decades after surgery $[11-13,89]$.

Table 1. Summary of evidence from research in human subjects for concepts of the gut-brain axis and the prion-like spreading/propagation of $\alpha$-synuclein in Parkinson's disease.

\begin{tabular}{|c|c|c|}
\hline Subjects/Specimens & Outcome/Results & Reference \\
\hline \multicolumn{3}{|c|}{ Gut Dysbiosis/SIBO } \\
\hline $\begin{array}{l}\text { Intestinal biopsy samples } \\
\text { from PD subjects and HC }\end{array}$ & $\begin{array}{l}\uparrow \text { intestinal permeability ( } \uparrow \text { urinary sucralose excretion, } \downarrow \\
\text { plasma LBP level) } \\
\uparrow E . \text { coli in lamina propria and epithelium } \\
\uparrow \text { inflammation/oxidative stress ( } \uparrow 3 \text {-NT) } \\
\uparrow \alpha \text {-syn immunoreactivity } \\
\text { in PD patients }\end{array}$ & Forsyth et al. 2011 [30] \\
\hline $\begin{array}{l}\text { Faecal samples from PD } \\
\text { patients and cohabitants }\end{array}$ & $\begin{array}{l}\downarrow \text { total fecal bacterial } \\
\downarrow \text { Clostridium coccoides (C. leptum) and Bacteroides fragilis } \\
\uparrow \text { Lactobacillus } \\
\text { L. gasseri counts correlated positively with disease } \\
\text { durations and negatively with stool frequencies } \\
\text { C. coccoides counts correlated negatively with disease } \\
\text { durations and positively with stool frequencies } \\
\uparrow \text { intestinal permeability ( } \downarrow \text { serum LBP level) } \\
\text { in PD patients }\end{array}$ & Hasegawa et al. 2015 [33] \\
\hline $\begin{array}{l}\text { Sigmoid mucosal biopsy and } \\
\text { faecal samples from PD } \\
\text { subjects and HC }\end{array}$ & $\begin{array}{l}\uparrow \text { putative proinflammatory bacteria from the family } \\
\text { Oxalobacteraceae (Proteobacteria, class } \\
\text { Betaproteobacteria) and genus Ralstonia (Proteobacteria, } \\
\text { class Betaproteobacteria, family Oxalobacteraceae) in the } \\
\text { mucosa } \\
\downarrow \text { putative "anti-inflammatory" butyrate-producing } \\
\text { bacteria from the genera Blautia, Coprococcus, and } \\
\text { Roseburia in faces } \\
\downarrow \text { microbiome genes involved in normal metabolic } \\
\text { activities of microbiota } \\
\uparrow \text { microbiome genes involved in bacterial secretion, LPS, } \\
\text { and ubiquinone biosynthesis } \\
\text { in PD patients }\end{array}$ & Keshavarzian et al. 2015 [31] \\
\hline $\begin{array}{l}\text { Fecal samples from PD } \\
\text { patients and HC }\end{array}$ & $\begin{array}{l}\downarrow \text { Prevotellaceae } \\
\uparrow \text { Enterobacteriaceae positively correlated with the } \\
\text { severity of postural instability and gait difficulty } \\
\uparrow \text { Verrucomicrobiaceae and Bradyrhizobiaceae associated } \\
\text { with the degree of constipation } \\
\text { in PD patients }\end{array}$ & Scheperjans et al. 2015 [34] \\
\hline $\begin{array}{l}\text { Fecal samples from PD } \\
\text { patients and HC }\end{array}$ & $\begin{array}{l}\downarrow \text { Dorea, Bacteroides, Prevotella, Faecalibacterium, Bacteroides } \\
\text { massiliensis, Stoquefichus massiliensis, Bacteroides coprocola, } \\
\text { Blautia glucerasea, Dorea longicatena, Bacteroides dorei, } \\
\text { Bacteroides plebeus, Prevotella copri, Coprococcus eutactus, } \\
\text { and Ruminococcus callidus } \\
\uparrow \text { Christensenella, Catabacter, Lactobacillus, Oscillospira, } \\
\text { Bifidobacterium, Christensenella minuta, Catabacter } \\
\text { hongkongensis, Lactobacillus mucosae, Ruminococcus bromii, } \\
\text { and Papillibacter cinnamivorans } \\
\text { in PD patients }\end{array}$ & Petrov et al. 2016 [35] \\
\hline $\begin{array}{l}\text { Fecal samples from PD } \\
\text { patients and HC }\end{array}$ & $\begin{array}{l}\downarrow \text { phyla Bacteroidetes and Prevotellaceae } \\
\downarrow \text { Lactobacillaceae and Enterococcaceae } \\
\downarrow \text { Faecalibacterium prausnitzii } \\
\uparrow \text { Bifidobacterium and Enterobacteriaceae } \\
\downarrow \text { SCFAs (acetate, propionate and butyrate) } \\
\text { in PD patients }\end{array}$ & Unger et al. 2016 [29] \\
\hline
\end{tabular}


Table 1. Cont.

\begin{tabular}{|c|c|c|}
\hline Subjects/Specimens & Outcome/Results & Reference \\
\hline $\begin{array}{l}\text { Stool samples from PD } \\
\text { patients and } \mathrm{HC}\end{array}$ & $\begin{array}{l}\uparrow \text { Verrucomicrobiaceae (genus Akkermansia, including } \\
\text { Akkermansia muciniphila and Alistipes shahii.) } \\
\uparrow \text { Firmicutes } \\
\downarrow \text { Prevotellaceae (genus Prevotella, including Prevotella } \\
\text { copri) } \\
\downarrow \text { Erysipelotrichaceae (genus Eubacterium, including } \\
\text { Eubacterium biforme) } \\
\downarrow \text { Clostridium saccharolyticum } \\
\downarrow \text { microbiome glucuronate pathway (D-Glucuronate } \\
\text { degradation, D-glucuronate } \rightarrow \text { pyruvate, and } \\
\text { D-glyceraldehyde) } \\
\uparrow \text { microbiome tryptophan pathway } \\
\text { (tryptophan } \rightarrow \text { kynurenine } \rightarrow 2 \text {-aminomuconate) } \\
\text { in PD patients }\end{array}$ & Bedarf et al. 2017 [36] \\
\hline $\begin{array}{l}\text { Stool samples of PD patients } \\
\text { and HC }\end{array}$ & $\begin{array}{l}\uparrow \text { Bifidobacteriaceae, Christensenellaceae, Tissierellaceae, } \\
\text { Lactobacillaceae, and Verrucomicrobiaceae families } \\
\downarrow \text { Lachnospiraceae, Pasteurellaceae } \\
26 \text { microbiome' metabolic pathways changed } \\
\text { in PD patients }\end{array}$ & Hill-Burns et al. 2017 [37] \\
\hline $\begin{array}{l}\text { Faecal samples from } \\
\text { drug-naive PD patients HCs. }\end{array}$ & $\begin{array}{l}\downarrow \text { Prevotellaceae, Lachnospiraceae, Lactobacillaceae and } \\
\text { Streptococcaceae } \\
\downarrow \text { phages belonged to the Siphoviridae family (Bacillus, } \\
\text { Enterobacteria, Lactococcus Streptococcus, and Salmonella } \\
\text { phages) and Lactobacillus phages of the Myoviridae family } \\
\uparrow \text { phages belonged to the Siphoviridae family (Leuconostoc, } \\
\text { Lactococcus, and Enterobacteria phages) Enterobacteria } \\
\text { phages of the Myoviridae family, and Salmonella phages of } \\
\text { the Podoviridae family } \\
\uparrow \text { phage/bacteria ratio for Lactococcus } \\
\text { in PD patients }\end{array}$ & Tetz et al. 2018 [38] \\
\hline $\begin{array}{l}\text { breath samples from PD } \\
\text { patients and HC }\end{array}$ & $\begin{array}{l}\text { SIBO ( } \uparrow \text { hydrogen level in GBT) } \\
\uparrow \text { bloating and flatulence } \\
\uparrow \text { motor complications (UPDRS-III) } \\
\text { in PD patients }\end{array}$ & Gabrielli et al. 2011 [39] \\
\hline $\begin{array}{l}\text { Breath samples from PD } \\
\text { patients and HC }\end{array}$ & $\begin{array}{l}\text { SIBO ( } \uparrow \text { hydrogen and methane levels in GBT and LBT) } \\
\uparrow \text { motor complications (UPDRS-IV) } \\
\text { in PD patients }\end{array}$ & Fasano et al. 2013 [40] \\
\hline $\begin{array}{l}\text { Breath samples from PD } \\
\text { patients and HC }\end{array}$ & SIBO ( $\uparrow$ hydrogen in LBT) in early stage PD & Tan et al. 2014 [41] \\
\hline $\begin{array}{l}\text { Urinary samples from PD } \\
\text { patients and HCs }\end{array}$ & SIBO ( $\uparrow$ urine indican concentrations) in PD patients & Cassani et al. 2015 [42] \\
\hline \multicolumn{3}{|c|}{ Peripheral distribution of $\alpha$-synuclein pathology } \\
\hline $\begin{array}{l}\text { Autopsy GI tissue samples } \\
\text { from PD subjects }\end{array}$ & LBs in the myenteric plexus of the lower oesophagus & Wakabayashi et al. 1988 [7] \\
\hline $\begin{array}{l}\text { Postmortem study of the } \\
\text { brain from PD subjects }\end{array}$ & $\begin{array}{l}\text { LBs in TH-positive neurons in the midbrain, pons, } \\
\text { medulla (DMV), rostral medial lemniscus, raphe } \\
\text { obscurus nucleus, dorsal tegmental bundle }\end{array}$ & Halliday et al. 1990 [72] \\
\hline $\begin{array}{l}\text { Autopsy GI specimens from } \\
\text { PD subjects }\end{array}$ & $\begin{array}{l}\text { LBs in the paravertebral and celiac sympathetic ganglia } \\
\text { and in the Auerbach's plexus of the lower upper, middle } \\
\text { and lower esophagus, duodenum, ileum, descending } \\
\text { colon and rectum, and Meissner's plexuses of the } \\
\text { duodenum and descending colon }\end{array}$ & Wakabayashi et al. 1990 [70] \\
\hline $\begin{array}{l}\text { Postmortem study of the } \\
\text { brain from PD subjects }\end{array}$ & LBs in DMV & Wakabayashi et al. 1999 [73] \\
\hline
\end{tabular}


Table 1. Cont.

\begin{tabular}{|c|c|c|}
\hline Subjects/Specimens & Outcome/Results & Reference \\
\hline $\begin{array}{l}\text { Postmortem study of the } \\
\text { brain from PD subjects }\end{array}$ & $\begin{array}{l}\text { LNs and LBs in non-catecholaminergic neurons of the } \\
\text { dorsal glossopharyngeus-vagus complex, projection } \\
\text { neurons of the intermediate reticular zone, olfactory } \\
\text { bulb, olfactory tract, and/or anterior olfactory nucleus }\end{array}$ & Del Tredici et al. 2002 [74] \\
\hline $\begin{array}{l}\text { Autopsy specimens of brains, } \\
\text { spinal cords and PANS from } \\
\text { PD subjects }\end{array}$ & $\begin{array}{l}\text { LNs in the intermediolateral nucleus of the thoracic } \\
\text { spinal cord, sacral parasympathetic cell column of the } \\
\text { sacral spinal cord, dorsal and anterior horns, } \\
\text { paravertebral chain ganglia, vagus nerve and DMV }\end{array}$ & Bloch et al. 2006 [69] \\
\hline $\begin{array}{l}\text { Autopsy stomach specimens } \\
\text { from PD subjects }\end{array}$ & $\begin{array}{l}\alpha \text {-syn aggregations, including LNs and LBs in the gastric } \\
\text { wall (peripheral nerve, fibers generated from the } \\
\text { Auerbach plexus, nerve fiber bundle of Meissner's } \\
\text { plexus), gastric Meissner plexus and Auerbach plexus }\end{array}$ & Braak et al. 2006 [55] \\
\hline $\begin{array}{l}\text { Postmortem study of the } \\
\text { brain and complete spinal } \\
\text { cords from PD subjects }\end{array}$ & $\begin{array}{l}\alpha \text {-syn aggregations, including LBs and LNs, in spinal } \\
\text { cord lamina I neurons, parasympathetic preganglionic } \\
\text { projection neurons of the vagal nerve, sympathetic } \\
\text { preganglionic neurons of the spinal cord, postganglionic } \\
\text { neurons of the coeliac ganglion }\end{array}$ & Braak et al. 2007 [75] \\
\hline $\begin{array}{l}\text { Autopsy brain tissues from } \\
\text { PD subjects }\end{array}$ & $\begin{array}{l}\text { LBs and LNs in the present in olfactory bulb and tract, } \\
\text { anterior olfactory nucleus, orbitofrontal cortex, } \\
\text { amygdala and hippocampus }\end{array}$ & Hubbard et al. 2007 [79] \\
\hline $\begin{array}{l}\text { Colonic biopsies from PD } \\
\text { patients }\end{array}$ & p- $\alpha$-syn immunoreactivity in the submucosal neurites & Lebouvier et al. 2008 [64] \\
\hline $\begin{array}{l}\text { Olfactory bulb sections from } \\
\text { PD patients }\end{array}$ & $\begin{array}{l}\text { synucleinopathy in the olfactory bulb } \\
\text { olfactory bulb synucleinopathy density scores correlated } \\
\text { significantly with: } \\
\text { those in other brain regions (anterior medulla, anterior } \\
\text { pons, midbrain, amygdala, gyrus, inferior parietal } \\
\text { lobule) } \\
\text { mini mental state examinations and UPDRS scale (motor } \\
\text { part) score }\end{array}$ & Beach et al. 2009 [80] \\
\hline $\begin{array}{l}\text { A whole-body autopsy of PD } \\
\text { subjects }\end{array}$ & $\begin{array}{l}\text { p- } \alpha \text {-syn immunoreactivity in the spinal cord and vagus } \\
\text { nerve as well as in the submandibular gland, in the } \\
\text { submucosa of the lower esophagus, in the stroma of the } \\
\text { pancreas, in the submucosa of a primary bronchus, in the } \\
\text { submucosa of the larynx, in the adrenal medulla, in the } \\
\text { stroma of the parathyroid gland, and in the ovary }\end{array}$ & Beach et al. 2010 [65] \\
\hline $\begin{array}{l}\text { Colonic biopsies from PD } \\
\text { patients }\end{array}$ & $\begin{array}{l}\text { p- } \alpha \text {-syn immunoreactivity in the submucosal neurites } \\
\text { and submucosal plexus } \\
\text { LP positively correlated with dysarthria and postural } \\
\text { instability, constipation severity }\end{array}$ & Lebouvier et al. 2010 [61] \\
\hline $\begin{array}{l}\text { Gastrointestinal specimens } \\
\text { from patients with no history } \\
\text { of neurological and } \\
\text { psychiatric diseases }\end{array}$ & $\begin{array}{l}\alpha \text {-syn mRNA expression in full-thickness sections and } \\
\text { intestinal wall layers (submucosa and tunica muscularis) } \\
\alpha \text {-syn mRNA expression in myenteric ganglia. } \\
\alpha \text {-syn immunoreactivity in ganglia of the myenteric and } \\
\text { submucosal plexus as well as in intramuscular nerve } \\
\text { fibers } \\
\text { p- } \alpha \text {-syn immunoreactivity in ganglia of the myenteric } \\
\text { and submucosal plexus }\end{array}$ & Böttner et al. 2012 [76] \\
\hline $\begin{array}{l}\text { Colonic biopsies from PD } \\
\text { patients }\end{array}$ & $\begin{array}{l}\mathrm{p}-\alpha \text {-syn immunoreactivity (including LNs) in the } \\
\text { ascending colon, descending colon and rectum }\end{array}$ & Pouclet et al. 2012 [62] \\
\hline $\begin{array}{l}\text { Colonic biopsies from PD } \\
\text { patients }\end{array}$ & $\alpha$-syn within neuronal tissues in the colonic submucosa & Shannon et al. 2012 [56] \\
\hline $\begin{array}{l}\text { Colonic biopsies from PD } \\
\text { patients }\end{array}$ & $\begin{array}{l}\alpha \text {-syn-positive structures in colonic submucosa } 2 \text { to } 5 \\
\text { years before the first reported symptom of PD }\end{array}$ & Shannon et al. 2012 [57] \\
\hline $\begin{array}{l}\text { Submandibular gland } \\
\text { autopsy in an elderly subject } \\
\text { with PD }\end{array}$ & p- $\alpha$-syn immunoreactivity in submandibular gland & Beach et al. 2013 [78] \\
\hline
\end{tabular}


Table 1. Cont.

\begin{tabular}{l} 
Subjects/Specimens \\
\hline Colonic specimens from PD \\
patients \\
\hline Submandibular gland \\
biopsies from PD patients \\
Multiorgan (including GI \\
tract) postmortem study of \\
PD subjects \\
\hline
\end{tabular}

GI tissue samples from patients with no history of neurological disease
Outcome/Results

$\alpha$-syn expression in myenteric and submucosal ganglia and extraganglionic nerve fibers

p- $\alpha$-syn immunoreactivity in nerve fibers or puncta within submandibular salivary gland tissue

p- $\alpha$-syn $/ \alpha$-syn immunoreactivity in the distal

esophagus, stomach, ileum, colon, and rectum (ganglia of the myenteric plexus) $\alpha$-syn immunoreactivity in the mucosal plexus of the vermiform appendix

$\alpha$-syn immunoreactivity in the CD68-immunoreactive macrophages in the appendiceal lamina propria $\alpha$-syn immunoreactivity in the mucosa of the stomach, ileum and colon

p- $\alpha$-syn immunoreactivity in the stomach, small intestine, large intestine,

$\alpha$-syn-positive neurites within the lamina propria and

GI tissue samples from PD patients submucosal myenteric nerve fibres

$\alpha$-syn small rounded inclusions within submucosal ganglia

$\alpha$-syn-positive biopsies correlated with autonomic symptoms (sometimes prior to motor symptoms)

\begin{tabular}{lll}
\hline $\begin{array}{l}\text { Colonic biopsies from PD } \\
\text { patients }\end{array}$ & $\begin{array}{l}\text { p- } \alpha \text {-syn immunoreactivity (LBs) in the submucosa } \\
\downarrow \text { occludin expression }\end{array}$ & Clairembault et al. 2015 [46] \\
\hline $\begin{array}{l}\text { Stomach biopsies from PD } \\
\text { patients }\end{array}$ & $\begin{array}{l}\alpha \text {-syn immunoreactivity (antrum, pylorus, and } \\
\text { duodenum) }\end{array}$ & Sánchez-Ferro et al. 2015 [68] \\
\hline $\begin{array}{l}\text { Colonic mucosal biopsies } \\
\text { from PD patients }\end{array}$ & $\begin{array}{l}\alpha \text {-syn and p- } \alpha \text {-syn immunoreactivity in individuals with } \\
\text { early PD and with later PD > control subjects }\end{array}$ & Visanji et al. 2015 [60] \\
\hline $\begin{array}{l}\text { colonic biopsies from PD } \\
\text { patients }\end{array}$ & $\begin{array}{l}\text { LTS in the lamina propria of the mucosa, submucosa, } \\
\text { and epithelium }\end{array}$ & Corbillé et al. 2016 [63]
\end{tabular}

PD Multiorgan (including GI p- $\alpha$-syn/ $\alpha$-syn immunoreactivity in the nasal region, tract) postmortem study of oral region, salivary gland, esophagus, stomach, small PD subjects intestine and appendix (mucosa, submucosal ganglia,

Stokholm et al. 2016 [67]

Gold et al. 2013 [58]

Adler et al. 2014 [77]

Gelpi et al. 2014 [66]

Gray et al. 2014 [87]

Hilton et al. 2014 [59] intramuscular nerve fibers, and myenteric ganglia)

\section{Vagotomy and risk of PD}

A cohort of individuals underwent vagotomy and matched general population (control)

Vagotomized patients (truncal, selective, and unknown); reference individuals

$\downarrow$ risk of PD in patients who underwent full truncal vagotomy

$\downarrow$ risk of PD in patients with truncal vagotomy vs. selective vagotomy

$\downarrow$ risk of PD in patients with truncal vagotomy vs. reference individuals (ns)
Svensson et al. 2015 [28]

Liu et al. 2017 [88]

\begin{tabular}{|c|c|c|}
\hline \multicolumn{3}{|c|}{ Prion-like spread of $\alpha$-synuclein } \\
\hline $\begin{array}{l}\text { An individual with PD } \\
\text { transplanted bilaterally with } \\
\text { human ventral } \\
\text { mesencephalon derived from } \\
\text { embryos-a post-mortem } \\
\text { examination }\end{array}$ & $\begin{array}{l}\uparrow \alpha \text {-syn and ubiquitin immunoreactivity } \\
\downarrow \text { DAT immunoreactivity } \\
\text { in grafted neurons } 14 \text { years after transplantation }\end{array}$ & Kordower et al. 2008 [11] \\
\hline $\begin{array}{l}\text { An individual with PD } \\
\text { transplanted bilaterally with } \\
\text { human ventral } \\
\text { mesencephalon derived from } \\
\text { embryos-a post-mortem } \\
\text { examination }\end{array}$ & $\begin{array}{l}\uparrow \alpha \text {-syn, ubiquitin and thioflavin S immunoreactivity } \\
\downarrow \text { DAT an TH immunoreactivity } \\
\text { in grafted neurons } 14 \text { years after transplantation }\end{array}$ & Kordower et al. 2008 [12] \\
\hline
\end{tabular}


Table 1. Cont.

\begin{tabular}{|c|c|c|}
\hline Subjects/Specimens & Outcome/Results & Reference \\
\hline $\begin{array}{l}\text { PD subjects transplanted } \\
\text { fetal mesencephalic } \\
\text { dopaminergic neurons-a } \\
\text { post-mortem examination }\end{array}$ & $\begin{array}{l}\uparrow \alpha \text {-syn immunoreactivity } \\
\downarrow \text { TH-positive neurons } \\
\text { in grafted neurons } 11-16 \text { years after transplantation }\end{array}$ & Li et al. 2008 [13] \\
\hline $\begin{array}{l}\text { PD subjects transplanted } \\
\text { fetal mesencephalic } \\
\text { dopaminergic neurons-a } \\
\text { post-mortem examination }\end{array}$ & $\begin{array}{l}\uparrow \alpha \text {-syn immunoreactivity } \\
\downarrow \text { DAT immunoreactivity } \\
\downarrow \text { TH-positive neurons } \\
\text { in grafted neurons } 13-22 \text { years after transplantation }\end{array}$ & Kurowska et al. 2011 [89] \\
\hline \multicolumn{3}{|c|}{$\begin{array}{l}\uparrow=\text { increase, } \downarrow=\text { decrease; 3-NT-3-nitrotyrosine; } \alpha \text {-syn- } \alpha \text {-synuclein; DAT-dopamine transporter; } \\
\text { DMV-vagal dorsal motor; GBT-glucose breath test; HC-healthy control; LBP-lipopolysaccharide-binding } \\
\text { protein; LBs-Lewy bodies; LBT-lactulose breath test; LNs-Lewy neurites; LP-Lewy pathology; } \\
\text { LTS-Lewy type synucleinopathy; LPS-Lipopolysaccharide; PANS-peripheral autonomic nervous system; } \\
\text { p- } \alpha \text {-syn-phosphorylated } \alpha \text {-synuclein; PD-Parkinson's disease; SCFAs-short-chain fatty acids; SIBO-small } \\
\text { intestinal bacterial overgrowth; TH-tyrosine hydroxylase; UPDRS-Unified PD Rating System. }\end{array}$} \\
\hline
\end{tabular}

\section{Evidence from Experimental Models}

Different lines of approach in animal model systems have been used to examine the role of the brain-gut-(microbiota) axis and the idea of prion-like spreading of $\alpha$-synuclein in the context of PD. These include the use of pesticide-induced synucleinopathy or xenograft models, germ-free or exposed to antibiotics animals, transgenic, engineered by viral vector or wild types animals as well as the use of different surgical procedures (Table 2).

In view of Braak's theory, an initial $\alpha$-synuclein pathology might be triggered by exogenous insults targeting the gut and/or olfactory system. Besides stochastic events leading to the de novo aggregation of endogenous $\alpha$-synuclein, exogenous agents such as toxins or inflammatory agents are proposed to initiate the pathology [90].

Since environmental exposure to pesticides has been reported to be associated with an increased risk of PD and the high expression of $\alpha$-synuclein in the brain [91], intragastric administration of the pesticide rotenone to rodents has been used to promote misfolding of $\alpha$-synuclein in the ENS. Pan-Montojo and co-workers [25] have demonstrated that $\alpha$-synuclein appears in the DMV, intermediolateral nucleus of the spinal cord and the SNpc in mice treated i.g. with rotenone [25]. It was later shown that the rotenone's effect on PD-like disease progression might be prevented by hemivagotomy or the resection of autonomic nerves [26]. The Braak's theory concerning the retrograde transport of the $\alpha$-synuclein pathology from the ENS to the CNS was verified by Phillips et al. [92], who have examined the pattern of expression of the protein in the autonomic circuitry of the proximal gut in aged rats. They have demonstrated the presence of $\alpha$-synuclein in vagal efferent axons and terminals originated in the DMV and in addition some of these preganglionic efferents terminated on $\alpha$-syn-positive neurons in the myenteric plexus of the stomach and duodenum. Vagotomy eliminated $\alpha$-synuclein distribution to most neurites in the plexus [92]. Also, findings of Noorian et al. [27] in transgenic mice have supported the idea that vagal innervation may be a critical factor for the development of $\alpha$-synuclein neuritic pathology in the GI tract since vagotomy resulted in the complete elimination of $\alpha$-synuclein in the appropriate terminal distribution. Remarkably, Ulusoy and co-workers [93] have postulated the ability of $\alpha$-synuclein to move both anterogradely and retrogradely as they demonstrated that the protein is also transferred from the brain to peripheral tissues via the DMV. Of note, similar to clinical evidence, gastrointestinal problems such as declined gastrointestinal motility, has been observed in transgenic mice expressing mutant $\alpha$-synuclein aggregates in the ENS ganglia [27,94], which appeared before motor dysfunctions [94]. There is also experimental evidence supporting Braak's hypothesis concerning the $\alpha$-synucleinopathy in the olfactory bulb. In Tg mice overexpressing A53T-mutant human $\alpha$-synuclein, the protein appeared in the olfactory bulb at an earlier stage than in the substantia nigra and its distribution positively correlated with age [95].

As was shown in the previous section, the changes in the composition of the gut microbiota correlate well with PD symptoms which, on the other hand, are associated with more extensive 
$\alpha$-synuclein deposition within the enteric nervous system. However, until now, it has not been clear if the changed gut microbiota plays a causative role in the pathogenesis of PD or is simply a consequence of the disease $[96,97]$. The possibility of the pathophysiological influence of gut bacteria on the neuro-immune system, in intestinal dysfunctions and CNS neurodegeneration, has been examined in several animal models of PD. Recently, Yang et al. [98] have demonstrated that in mice with rotenone-induced PD microbiome dysbiosis, colonic inflammation, enteric abnormal $\alpha$-synuclein accumulation, and gastrointestinal dysfunction appeared before motor dysfunction and CNS pathology. The gut dysbiosis was characterized by an overall decrease in bacterial diversity and an increase in Firmicutes/Bacteroidetes ratio and consequent changes in 11 metabolic pathways. This finding supports the view that alterations of the enteric bacteria-immune network could contribute to CNS pathology [98]. Gut dysbiosis and/or small intestinal overgrowth have been suggested to induce over-response of the immune system and consequently systemic and/or CNS inflammation [32,47]. Sampson and co-workers [99] have demonstrated that $\alpha$-synuclein in transgenic mice under germ-free (GF) conditions displayed reduced abnormal $\alpha$-synuclein accumulation in the brain. Additionally, a positive feedback loop involving decreased GI and motor dysfunctions and microglia activation in conjunction with GF conditions and bacterial depletion by antibiotics has been demonstrated in animals overexpressing $\alpha$-synuclein. Based on these observations it could be suggested that gut microbiota contributes to central PD pathology by potentiating microglial activation and neuroinflammation and related motor and GI dysfunctions and, importantly, that treatment with antibiotics can provide an improvement of gastrointestinal and central symptoms of the disease. Moreover, microbiota transplants from PD patients enhanced gut dysfunctions and motor impairment as compared to microbiota transplantation from healthy controls [99]. In aged Fischer rats, treated with E. coli producing bacterial amyloid protein curli, which is a $\beta$-sheet-rich protein capable of cross-seeding, an increased neuronal expression of $\alpha$-synuclein has been demonstrated both in the submucosal and myenteric plexus as well as in the brain, which correlated well with enhanced microgliosis and astrogliosis [100]. The relation between alterations of the intestinal epithelial barrier and enteric inflammatory responses was investigated in animals with experimental PD induced by lipopolysaccharide (LPS) [101]. In this study, an abnormal intestinal permeability appeared in the early phase of the disease, before $\alpha$-synuclein accumulation in the ENS and SN [101]. Moreover, a recent study has demonstrated an increased expression of $\alpha$-synuclein in the cortex of peptidoglycan recognition protein 2 (Pglyrp2)-knockout mice, supporting the idea that disrupted gut flora and immune response, as seen in the Pglyrp2-knockout animal could be a causative factor in PD [102]. Taken together, these studies highlight the crucial roles of dysbiosis in the initiation and/or progression of the neurodegeneration, often associated with activation of neuroinflammatory processes. In this concept, an abnormal microbiota composition (or anomalous host response to a normal microbiota) leads to a local immune response as well as an altered level of bacterial metabolites. These may evoke impairment in the gastrointestinal mucosal barrier ("leaky gut") that enables migration of gut bacteria and inflammatory cytokines, triggering a systemic inflammatory response, which, in turn, impairs the blood-brain barrier and promotes neuro-inflammation and ultimately, neuronal degeneration. These effects may be exacerbated by abnormal signaling through the vagus nerve, caused by some microbial metabolites acting as neurotransmitters and neuromodulators $[103,104]$.

Considerable efforts have been undertaken to study, both within the ENS and CNS, spreading routes with a focus on understanding the plausibility of the prion-like behavior of $\alpha$-synuclein pathology. Since currently, it is not possible to monitor precisely progress of the LP in an individual, different animal models have been developed to trigger and subsequently examine synucleinopathy at different time points. Injections of rodents with exogenous $\alpha$-synuclein have been demonstrated to initiate a cascading seeding event from the injection site that has been interpreted as a prion-like behavior of $\alpha$-synuclein pathology. Preformed fibrillar $\alpha$-synuclein assemblies (PFFs) injected intraperitoneally or intraglossally led to the distribution of $\alpha$-synuclein pathology to the brain and spinal cord [105]. $\alpha$-Synuclein from the human PD brain injected into the stomach [106] or 
intestine [107] of rodents is transferred to the myenteric neurons [106] as well as to the DMV via the vagal nerve in a time-dependent manner [107]. After a single peripheral intramuscular injection of recombinant fibrillar $\alpha$-synuclein, its pathological inclusions were also detected in the spinal cord, brainstem, midbrain, and cortex [108]. When PFFs were injected into the olfactory bulb, they triggered the spread of aggregated $\alpha$-synuclein pathology in an anatomical pattern within the brain [109]. Intracerebral inoculations with preformed recombinant human or mouse fibrils of $\alpha$-synuclein have been shown to promote the formation and spread of $\alpha$-synuclein pathology, including LB/LN-like inclusions, in the brain [110-115] and even along the other part of the CNS [116,117]. The acceleration of $\alpha$-synuclein aggregation in the brain of presymptomatic animals also followed intracerebral inoculation of brain tissue from mice or patients affected by the synucleinopathy [112,116-120]. A delivery of synuclein with Lewy-like pathology into the brain with viral vectors led to the same effects $[93,110,113,121]$. In addition, Angot et al. [122] have reported that h $\alpha$-syn transferred from a host brain, with engineered nigral neurons, to grafted embryonic ventral mesencephalon (VM). Similarly, transmission of h $\alpha$-syn from host to grafted mouse cortical neural stem cells was observed in transgenic mice expressing human $\alpha$-synuclein [123]. Chandra et al. [124] have discovered the presence of h $\alpha$-syn in enteroendocrine cells (EECs) in transgenic mice expressing human $\alpha$-synuclein and endogenous green fluorescent protein in cholecystokinin cells. Consistently with this massive burden of $\alpha$-synuclein pathology, early onset of neurological symptoms have been revealed in conditions including: a reduction in DAergic neurons [113-116,120], induction of cell death [123], loss of neurotransmitters such as dopamine [115] and enkephalin [112], inflammatory response [106,108,110,111,118], impairment of synaptic physiology [113] and protein degradation $[105,111]$. Consequently, the acceleration and increased accumulation of $\alpha$-synuclein pathology was associated with motor $[94,105,108,111,113,115,117-120]$ or olfactory impairment [109] and a reduction in survival rate $[108,116,118]$. These findings seem to be convincing and indicate that $\alpha$-synuclein assemblies can spread. Moreover, several studies in animal models have provided insight into mechanisms underlying this process. Angot et al. [122] have shown that in rats driven by AAV2/6 vector $\alpha$-synuclein aggregation, $\alpha$-synuclein is transferred to grafted dopaminergic neurons in the not aggregated and not phosphorylated form with the involvement of endocytosis for $\alpha$-synuclein uptake. This possibility was raised recently by Mao et al. [115] in TgLag3 mice, who have confirmed that the cell-to-cell transmission of misfolded $\alpha$-synuclein involves the uptake of the pathogenic particle from the outside of the cell by endocytosis, that is mediated by the cell surface receptor LAG3 or neurexin $1 \beta$ and amyloid $\beta$ precursor-like. Finally, the recent discovery in transgenic mice by Chandra et al. [124] demonstrated that sensory cells of the gut EECs, which are exposed to pathogen or toxin in the gut lumen, contain $\alpha$-synuclein. Since the functional synaptic connection between EECs and enteric nerves was established, it may provide a possible explanation for how PD may originate in the gut. Collectively, all the above-discussed data from animal studies seem to support the concept of the gut-to-brain transmission of PD pathology in the "prion-like" fashion. 
Table 2. Summary of evidence from animal studies for concepts of the gut-brain axis and prion-like propagation of $\alpha$-synuclein in Parkinson's disease.

\begin{tabular}{|c|c|c|}
\hline Experimental Model & Outcome/Results & Reference \\
\hline \multicolumn{3}{|c|}{ Dysbiosis } \\
\hline $\begin{array}{l}\text { ASO mice under GF } \\
\text { condition }\end{array}$ & $\begin{array}{l}\downarrow \text { p- } \alpha \text {-syn and aggregation-specific } \alpha \text {-syn } \\
\text { immunoreactivity in the CP and SN } \\
\downarrow \alpha \text {-syn insoluble expression } \\
\uparrow \text { numbers and total lengths of microglia branches } \\
\text { within the CP and SN ( } \downarrow \text { activation state) } \\
\downarrow \text { Iba- } 1 \text { immunoreactivity in microglia in the CP } \\
\downarrow \text { TNF- } \alpha \text { and IL- } 6 \text { in the CP, Mid and FC } \\
\uparrow \text { motor function (beam traversal, pole descent, and } \\
\text { hindlimb clasping reflexes) } \\
\uparrow \text { fecal pellets } \\
\downarrow \text { SCFAs production }\end{array}$ & Sampson et al. 2016 [99] \\
\hline $\begin{array}{l}\text { ASO mice under SPF } \\
\text { condition }\end{array}$ & $\begin{array}{l}\uparrow \text { motor function (beam traversal, pole descent, and } \\
\text { hindlimb clasping reflexes) } \\
\downarrow \text { Iba- } 1 \text { immunoreactivity in microglia in the CP } \\
\downarrow \text { microglia diameter in the CP and SN ( } \downarrow \text { activation state) } \\
\uparrow \text { fecal pellets } \\
\downarrow \text { SCFAs production }\end{array}$ & Sampson et al. 2016 [99] \\
\hline $\begin{array}{l}\text { ASO mice treated (p.o.) with } \\
\text { microbiota from PD patients }\end{array}$ & $\begin{array}{l}\downarrow \text { fecal pellets } \\
\downarrow \text { motor function (beam traversal, pole descent and nasal } \\
\text { adhesive removal) }\end{array}$ & Sampson et al. 2016 [99] \\
\hline $\begin{array}{l}\text { Male C57BL/ } 6 \text { mice treated } \\
\text { with rotenone (i.g.) }\end{array}$ & $\begin{array}{l}\downarrow \text { Bacteroidetes } \\
\uparrow \text { Firmicutes and Firmicutes/Bacteroidetes ratio } \\
\uparrow 11 \text { metabolic pathways } \\
\uparrow \alpha \text {-syn and p- } \alpha \text {-syn immunoreactivity in the colon } \\
\uparrow \alpha \text {-syn and p- } \alpha \text {-syn immunoreactivity in the midbrain } \\
\downarrow \text { colon motility and stool water content } \\
\downarrow \text { locomotor deficits in the open field and pole tests } \\
\uparrow \text { TNF- } \alpha \text {, IL- } 6 \text { and iNOS expression } \\
\uparrow \text { TLR2 expression }\end{array}$ & Yang et al. 2017 [98] \\
\hline \multicolumn{3}{|c|}{ Peripheral distribution of $\alpha$-synuclein } \\
\hline $\begin{array}{l}\text { Subdiaphragmatic vagotomy } \\
\text { in aged Fischer } 344 \text { and SD } \\
\text { rats }\end{array}$ & $\begin{array}{l}\downarrow \alpha \text {-syn-positive varicosities within ganglia and } \\
\alpha \text {-syn-positive axons in fiber bundles }\end{array}$ & Phillips et al. 2008 [92] \\
\hline $\mathrm{Tg}$ A53T and A30P mice & $\begin{array}{l}\alpha \text {-syn immunoreactivity within myenteric and } \\
\text { submucosal plexuses } \\
\downarrow \text { WGTT and colonic motility } \\
\downarrow \text { motor behavior (open field test, rotarod test) }\end{array}$ & Kuo et al. 2010 [94] \\
\hline $\begin{array}{l}\text { C57BL/6J mice treated with } \\
\text { rotenone (i.g.) }\end{array}$ & $\begin{array}{l}\uparrow \alpha \text {-syn phosphorylation, accumulation and aggregation } \\
\text { with gliosis in ENS ganglia } \\
\uparrow \text { intracellular and axonal } \alpha \text {-syn in the spinal cord and } \\
\text { the brainstem (IML and DMV); the } \alpha \text {-syn pathology } \\
\text { progressed into the SN }\end{array}$ & Pan-Montojo et al. 2010 [25] \\
\hline TgA53T mice & $\begin{array}{l}\alpha \text {-syn immunoreactivity in the olfactory bulb } \\
\text { (glomerular, mitral, and granule layers) } \\
\text { high } \alpha \text {-syn immunoreactivity in the calcium binding } \\
\text { protein-positive cells } \\
\text { low } \alpha \text {-syn immunoreactivity in the Nissl-positive cells }\end{array}$ & Ubeda-Bañon et al. 2010 [95] \\
\hline $\begin{array}{l}\text { TGA53T mice injected with } \\
\text { human brain tissue extract } \\
\text { containing LBs into the } \\
\text { stomach wall }\end{array}$ & $\begin{array}{l}\uparrow \alpha \text {-syn deposition in the myenteric neurons } \\
\uparrow \text { activation of macrophages (MHC-II expression) }\end{array}$ & Lee et al. 2011 [106] \\
\hline $\begin{array}{l}\text { Subdiaphragmatic vagotomy } \\
\text { in TgA53T mice }\end{array}$ & $\begin{array}{l}\downarrow \alpha \text {-syn immunoreactivity in the myenteric plexus of the } \\
\text { dorsal and ventral stomach and duodenum }\end{array}$ & Noorian et al. 2012 [27] \\
\hline
\end{tabular}


Table 2. Cont.

\begin{tabular}{|c|c|c|}
\hline Experimental Model & Outcome/Results & Reference \\
\hline $\begin{array}{l}\text { Hemivagotomy or partial } \\
\text { sympathectomy of the } \\
\text { nervus mesentericus inferior } \\
\text { in mice orally treated with } \\
\text { rotenone }\end{array}$ & $\begin{array}{l}\downarrow \alpha \text {-syn expression in the lumbal IML of SRT mice } \\
\downarrow \alpha \text {-syn expression in the ipsilateral DMV of HRT mice } \\
\uparrow \text { dopaminergic cell death in the ipsilateral SNc of HRT } \\
\text { mice } \\
\downarrow \text { motor deficits (rotarod test) }\end{array}$ & Pan-Montojo et al. 2012 [26] \\
\hline $\begin{array}{l}\text { SD rats injected with brain } \\
\text { lysates from PD patient into } \\
\text { the intestine wall of stomach } \\
\text { and duodenum }\end{array}$ & $\begin{array}{l}\alpha \text {-syn immunoreactivity in the intestinal wall and in the } \\
\text { vagal nerve as well as in ChAT-positive neurons in the } \\
\text { DMV (microtubule associated transport) }\end{array}$ & Holmqvist et al. 2014 [107] \\
\hline $\begin{array}{l}\text { C57 / BL6 mice treated with } \\
\text { LPS }\end{array}$ & $\begin{array}{l}\uparrow \alpha \text {-syn expression in the large intestine } \\
\text { p- } \alpha \text {-syn in colonic myenteric neurons } \\
\uparrow \text { intestinal permeability }\end{array}$ & Kelly et al. 2014 [101] \\
\hline $\begin{array}{l}\text { Aged Fischer rats fed with } E \text {. } \\
\text { coli producing amyloid } \\
\text { protein curli }\end{array}$ & $\begin{array}{l}\uparrow \alpha \text {-syn deposition in gut ganglion cells (myenteric } \\
\text { plexus and submucosa) and in neurons in hippocampus } \\
\text { and striatum } \\
\uparrow \text { Iba- } 1 \text { and GFAP immunoreactivity in the striatum, } \\
\text { hippocampus and neocortex }\end{array}$ & Chen et al. 2016 [100] \\
\hline \multicolumn{3}{|c|}{ Prion-like spread of $\alpha$-synuclein } \\
\hline $\begin{array}{l}\text { Thy-1 } \alpha \text {-syn TG mice } \\
\text { injected with MCNSCs into } \\
\text { the hippocampus }\end{array}$ & $\begin{array}{l}\text { h } \alpha \text {-syn immunoreactivity in MCNSCs } \\
\text { caspase } 3 \text { immunoreactivity in MCNSCs }\end{array}$ & Desplats et al. 2009 [123] \\
\hline $\begin{array}{l}\text { SD rats with engineered } \\
\text { nigral neurons to express } \\
\text { h } \alpha \text {-syn by AAV } 2 / 6 \\
\text { intrastriatally transplanted } \\
\text { with embryonic VM neurons }\end{array}$ & $\begin{array}{l}\text { h } \alpha \text {-syn immunoreactivity in grafted neurons } \\
\text { EEA1-positive transmitted h } \alpha \text {-syn } \\
\text { PK-sensitive and } p \text { - } \alpha \text {-syn-negative transmitted h } \alpha \text {-syn }\end{array}$ & Angot et al. 2012 [122] \\
\hline $\begin{array}{l}\text { TgM83 mice inoculated } \\
\text { intracerebrally with } \\
\text { symptomatic aged M } 83 \text { brain } \\
\text { lysates harbouring } \\
\text { aggregated } \alpha \text {-syn or PFFs }\end{array}$ & $\begin{array}{l}\text { p- } \alpha \text {-syn immunoreactivity in the CNS } \\
\text { thioflavin-S- and Ub-positive inclusions in the CNS } \\
\downarrow \text { TH-positive neurons } \\
\uparrow \text { GFAP and Iba- } 1 \text { immunoreactivity in the CNS } \\
\downarrow \text { survival period }\end{array}$ & Luk et al. 2012 [116] \\
\hline $\begin{array}{l}\text { Young TgM } 83 \text { mice } \\
\text { inoculated intracerebrally } \\
\text { with homogenates of the } \\
\text { brain of old TgM } 83 \text { mice }\end{array}$ & $\begin{array}{l}\text { p- } \alpha \text {-syn expression in the brain homogenate } \\
\text { p- } \alpha \text {-syn immunoreactivity in diffuse perikaryal } \\
\text { inclusions and dystrophic neurites } \\
\text { paralysis } \\
\downarrow \text { survival period }\end{array}$ & Mougenot et al. 2012 [119] \\
\hline $\begin{array}{l}\text { C57BL/ } 6 \text { J mice injected into } \\
\text { substantia nigra with } \\
\text { recombinant } \alpha \text {-synuclein } \\
\text { monomer, fibrils or insoluble } \\
\text { fraction of brain tissue from } \\
\text { DLB patients }\end{array}$ & $\begin{array}{l}\text { p- } \alpha \text {-syn immunoreactivity as well as Ub- and } \\
\text { p62-positive inclusions in the brain including substantia } \\
\text { nigra, amygdala, dentate gyrus, hippocampus, fimbria, } \\
\text { stria terminalis, hypothalamus, somatosensory area, } \\
\text { visual cortex, cingulate cortex and corpus callosum } \\
\downarrow \text { enkephalin }\end{array}$ & $\begin{array}{l}\text { Masuda-Suzukake et al. } 2013 \\
\text { [112] }\end{array}$ \\
\hline $\begin{array}{l}\text { C57BL/ } 6 \text { mice } \\
\text { intracerebrally inoculated } \\
\text { with human LB fraction } \\
\text { Rhesus monkeys } \\
\text { intrastriatally inoculated } \\
\text { with human LB fraction }\end{array}$ & $\begin{array}{l}\text { Mice: } \\
\text { p- } \alpha \text {-syn immunoreactivity in the striatum and } \\
\text { neocortical areas } \\
\downarrow \text { SNpc TH-positive and Nissl-positive neurons } \\
\uparrow \text { Iba1-positive cells in the SNpc } \\
\uparrow \text { impaired motor ability (pole test) } \\
\text { Monkey } \\
\text { p- } \alpha \text {-syn immunoreactivity in the in the putamen, SNpc, } \\
\text { globus pallidus, precentral gyrus, superior frontal gyrus, } \\
\text { and the entorhinal area in the temporal cortex } \\
\downarrow \text { SNpc TH-positive neurons } \\
\downarrow \text { striatal dopaminergic innervation and dopaminergic } \\
\text { terminal }\end{array}$ & Recasens et al. 2014 [120] \\
\hline $\begin{array}{l}\text { SD rats injected with } \\
\text { h } \alpha \text {-synuclein-AAVs into the } \\
\text { vagus nerve, controls }\end{array}$ & $\begin{array}{l}\text { h } \alpha \text {-syn immunoreactivity in DMV and nucleus } \\
\text { ambiguous, MO, pons and midbrain } \\
\uparrow \text { rat and total (rat +human) } \alpha \text {-syn mRNA vs. controls in } \\
\text { MO }\end{array}$ & Ulusoy et al. 2013 [121] \\
\hline
\end{tabular}


Table 2. Cont.

\begin{tabular}{l} 
Experimental Model \\
\hline $\begin{array}{l}\text { TgM83 mice injected } \\
\text { intracerebrally with brain } \\
\text { homogenate from MSA } \\
\text { patients }\end{array}$ \\
$\begin{array}{l}\text { M20 and M83Tg mice } \\
\text { intracerebrally injected with } \\
\text { recombinant amyloidogenic } \\
\text { or soluble } \alpha \text {-syn }\end{array}$
\end{tabular}

TgM83 TgM20 mice injected intramuscularly with a fibrillar mouse or human $\alpha$-syn

Outcome/Results

Reference

p- $\alpha$-syn in the striatum, motor cortex, and thalamus

$\uparrow$ GFAP and Iba-1 immunoreactivity in the brainstem

neurologic dysfunction (ataxia, dysmetria, bradykinesia, Watts et al. 2013 [118] and circling behaviour)

$\downarrow$ survival periods

p- $\alpha$-syn immunoreactivity in the hippocampus, cortex,

striatum, midbrain, and brainstem, amygdala, thalamus,

and hypothalamus

Sacino et al. 2014 [111]

NFL and p62 -reactive inclusions

$\uparrow$ GFAP and Iba-1 immunoreactivity in the brain

hind limb paralysis

p- $\alpha$-syn immunoreactivity in the spinal cord, brainstem,

midbrain, and cortex (astrocytes and neurons)

p62 immunoreactivity in the brain and spinal cord

Sacino et al. 2014 [108]

$\uparrow$ GFAP and Iba- 1 immunoreactivity in the CNS

$\downarrow$ motor function

$\downarrow$ survival period

Wistar rats injected with $\alpha$-syn (oligomers, fibrils or ribbons) into $\mathrm{SN}$ or striatum and rAAV-driven $\alpha$-syn overexpression

$\mathrm{p}$ - $\alpha$-syn immunoreactivity in the whole brain

p62-positive inclusions

$\downarrow$ TH-positive neurons, dopaminergic cells, projecting axons

$\downarrow$ spontaneous bursts of action potentials in synapses $\uparrow$ motor deficit ( $\downarrow$ forelimb contacts in the cylinder test)

TgM83 mice injected intraperitoneally or intraglossally with fibrils of human or mouse $\alpha$-synuclein

$\mathrm{p}$ - $\alpha$-syn immunoreactivity in the brain and spinal cord Sarkosyl-insoluble and Ub- and p62-positive inclusions in the brain and spinal cord

$\uparrow$ GFAP and Iba-1 immunoreactivity in the brain paralysis, kyphosis, $\downarrow$ activity $\downarrow$ body weight

$\uparrow \mathrm{p}$ - $\alpha$-syn immunoreactivity in the SNpc TH-positive

WT and TgLag3 mice striatally injected with $\alpha$-syn PFFs neurons

$\downarrow$ TH- and Nissl-positive neurons in the SNpc

$\downarrow$ DA, DOPAC, HVA

Mao et al. 2016 [115]

$\downarrow$ TH and DAT

$\downarrow$ motor function (pole and hindlimb clasping tests)

C57BL/6J mice injected with mPFFs or HuPFFs into OB

p- $\alpha$-syn immunoreactivity within olfactory and brain

regions (above 40 brain regions and subregions)

$\uparrow$ p62-, Ub-, and thioflavin S-positive inclusions

Peelaerts et al. 2015 [113]

$\uparrow$ olfactory dysfunction

C57BL/6 J and $\mathrm{C} 3 \mathrm{H} / \mathrm{HeJ}$ mice and SD rats intracranially injected with $\alpha$-syn fibrils or monomer

$\mathrm{p}$ - $\alpha$-syn immunoreactivity in the SNpc, striatum, amygdala, cortex, and thalamus

$\downarrow$ TH-positive and Nissl-positive neurons in the SNpc

Rey et al. 2016 [109]

$\alpha$-syn immunoreactivity in EECs of duodenum and colon

Tg A53T;CCK-GFP 1 mice $\quad \alpha$-syn immunoreactivity in submucosal enteric nerves TH-positive EECs

$\alpha$-syn in regions of GFAP-positive glial processes

B6/C3H mice injected intraventricularly with rAAV-EV and

p- $\alpha$-syn immunoreactivity in the whole brain argyrophilic and p62 immunoreactive inclusions intrahippocampally with $\alpha$-syn fibrils

$\uparrow$ GFAP and Iba-1 immunoreactivity in the forebrain

TgM83 mice injected intraperitoneally or intracerebrally with brains homogenates of sick M83 mice or MSA patients p- $\alpha$-syn immunoreactivity in the cerebellum, cerebral cortex, striatum, brainstem, mesencephalon, and in the spinal cord hind limb paralysis, balance disorder $\downarrow$ survival periods $\mathrm{p}$ - $\alpha$-syn expression in the brainstem
Chandra et al. 2017 [124]

Koller et al. 2017 [110] 
Table 2. Cont.

\begin{tabular}{|c|c|}
\hline Experimental Model & Outcome/Results \\
\hline $\begin{array}{l}\text { SD rats injected with } \\
h \alpha \text {-synuclein-AAVs into the } \\
\text { vagus nerve or the midbrain }\end{array}$ & $\begin{array}{l}\text { h } \alpha \text {-syn immunoreactivity in DMV, nodose ganglion, } \\
\text { efferent DMV projections and afferent vagal fibers, MO, } \\
\text { NTS and gastric wall after vagal injection } \\
\text { h } \alpha \text {-syn-immunoreactivity in the striatum, hypothalamus, Ulusoy et al. } 2017 \text { [93] } \\
\text { locus coeruleus, MO, DMV neurons, and gastric wall } \\
\text { after midbrain injection }\end{array}$ \\
\hline $\begin{array}{l}\uparrow \quad \text { increase, } \downarrow \\
\text { (alpha-synuclein-overexpr } \\
\text { CP-caudoputamen; DA } \\
\text { DMV-vagal dorsal moto } \\
\text { EECs-enteroendocrine ce } \\
\text { fibrillary acidic protein; ho } \\
\text { human } \alpha \text {-syn preformed } \\
1 ; \text { IL-6-Interleukin 6; I } \\
\text { synthase; LBs-Lewy bodi } \\
\text { histocompatibility comple } \\
\text { MSA-multiple system at } \\
\text { solitaries; OB-olfactory } \\
\alpha \text {-synuclein; PK-protein } \\
\text { SNpc-substantia nigra pa } \\
\text { rotenone-treated; TH-ty } \\
\text { VM-ventral mesencephalc } \\
\text {-transgenic, WGTT-whol }\end{array}$ & 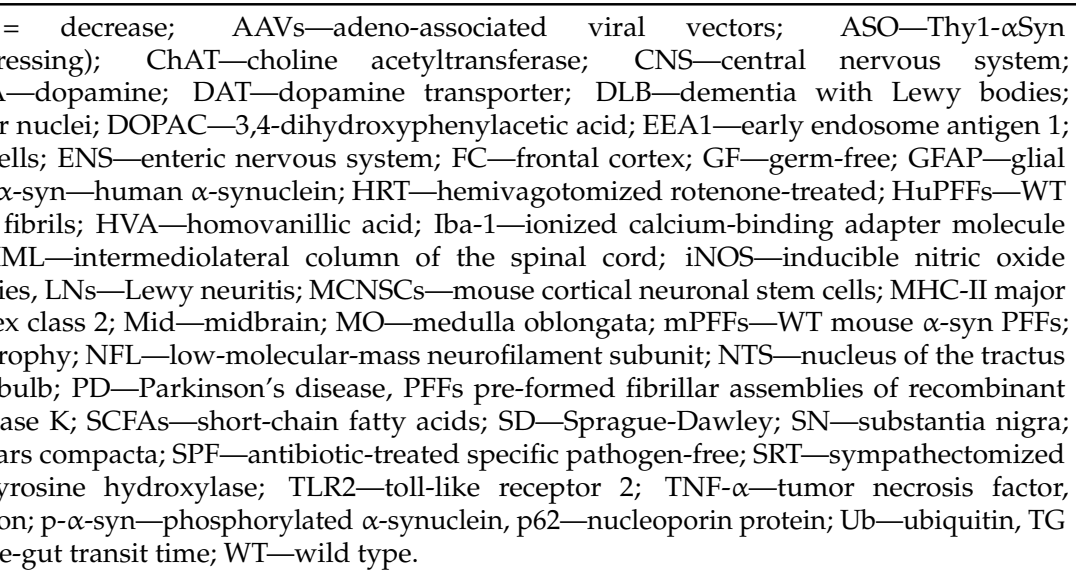 \\
\hline
\end{tabular}

\section{Does Parkinson's Disease Actually Originate in the Gut?}

All the above-summarized data seem to be convincing and supporting the concept of a gut-to-brain transmission of PD pathology. However, when reviewing the available literature, we also came across a doubt as to whether these data actually describes the disease's development in all PD patients. Of note, there are a few reports indicating that not all PD cases strictly follow Braak's staging system. Kalaitzakis et al. [125] reported that $47 \%$ of PD cases coming from a UK tissue bank did not match the predicted caudorostral distribution of LP in the brain, including the absence of prominent DMV pathology in $7 \%$ of cases. Similarly, the Braak's scheme did not fit in $18.3 \%$ of PD cases from the Vienna tissue brain bank, including 8.3\% in which the DMV was not involved at all [126]. Moreover, the hypothesis of peripheral onset of PD is questioned, since there is the relative lack of postmortem cases with a presence of $\alpha$-synuclein pathology in the PNAS without concomitant CNS involvement. Only Fumimura et al. [127] have demonstrated the occurrence of LBs in the adrenal glands, but in only 2 cases out of 783, in which the pathology was not detected in the CNS. Also, a protective effect of truncal vagotomy demonstrated by Svensson et al. [28] has been questioned by a Norwegian research group [128], who independently reanalyzed the Danish vagotomy dataset. As Tysnes and colleagues [128] included only 4050 patients with full truncal vagotomy, in contrast to 5339 patients from the study by Svensson et al. [28], any significant difference for the risk of PD between the vagotomy group and reference matched populations has been shown [128]. Supporting this, recently, Recasens et al. [129] have argued against a pathogenic ability of peripheral $\alpha$-synuclein assemblies in promoting $\alpha$-synuclein pathology in the brain. In their study intracerebral inoculation of mice with $\alpha$-synuclein aggregates from postmortem PD stellate ganglia (paravertebral sympathetic ganglion) triggered neither nigrostriatal neurodegeneration nor $\alpha$-synuclein pathology in the SNpc [129]. However, contrary to these findings in their previous report nigral LB extracts from PD patients administered intracerebrally to animals induced $\alpha$-synuclein pathology, neuroinflammation and finally neurodegeneration in the SNpc [120].

\section{Concluding Remarks}

Based on the gathered evidence from human and animal research that has been published over the last few decades, it is likely that $\alpha$-synuclein pathology originating within the gastrointestinal 
tract spreads via a prion-like mechanism. As depicted in Figure 1 there is growing concern within the scientific communities about this concept in PD pathology.

Given the abundance of evidence, it could be speculated that in PD, the gut is affected at the earliest. PD patients are characterized by abnormal gut microbiota composition, impairment of the intestinal barrier and enteric neuro-immune system that lead to enteric inflammation that contributes to neuroinflammation and neurodegeneration in the CNS. This data has been supported by findings from animal experiments. Other lines of evidence indicate that the intestine is the site where the aggregation of endogenous $\alpha$-synuclein occurs initiating the progression of PD. It has been widely supported by reports, demonstrating that Lewy pathology appears in peripheral tissues up to 20 years prior to PD diagnosis. There is considerable evidence that the olfactory regions might also be the starting point of synucleinopathy which can be explained by the fact that their neurons are exposed directly to environmental agents. In line with this, constipation and hyposmia appear years or decades prior to PD diagnosis. So far, the hypothesis that LP propagates from the ENS by trans-synaptic cell-to-cell transmission through sympathetic and parasympathetic nerves to the DMV into the CNS is controversial. As some PD patients do not follow Braak's staging system $[125,126]$, there is criticism concerning the pattern of spreading of $\alpha$-synuclein pathology $[47,130]$. On the other hand, lack of standardized methods of $\alpha$-synuclein detection and the inability to detect all its pathological forms are suggested to be the reason for differences in the experimental findings $[85,130]$. Nevertheless, studies reporting the decreased risk of PD following truncal vagotomy support the route of $\alpha$-synuclein pathology from the ENS to the CNS. The different findings of Norwegian and Danish studies could be explained by not imposing, in the Norwegian analysis, a minimum follow-up time from vagotomy to PD diagnosis required for exclusion patients with the conceivable pathology in the brain stem already at the time of vagotomy [85]. The convincing evidence of the prion-like mechanism of $\alpha$-synuclein pathogenesis came from postmortem observations that pathological $\alpha$-synuclein inclusions appeared in healthy grafted neurons. Finally, accumulating evidence from animal research demonstrates spreading of $\alpha$-synuclein pathology following peripheral administration of its pathological aggregates. However, in the light of the recent report of Recasens et al. [129] further studies are required to identify the exact composition and structure of LP from the PNAS and CNS in order to provide insight into a possible maturation of $\alpha$-synuclein needed for acquiring pathogenic features. In the context of the "prion-like" mechanism of PD, it should be noted that a few experimental studies have reported endocytic mechanisms involving contact of $\alpha$-synuclein with LAG3 receptors. Since the receptors are expressed on immune cells and/or neurons of the GI tract, it supports the hypothesis that PD may indeed originate within the gastrointestinal tract.

In this review, we frame current evidence for the gut-to-brain hypothesis of PD in the context of prion-like spreading of $\alpha$-synuclein. However, much remains to be discovered regarding the gut bacteria-neuro-immune crosstalk, the route for the spread of $\alpha$-synuclein pathology from the ENS to the CNS and its cellular transmission. It is believed that standardization of $\alpha$-synuclein detection methods and the development of techniques that enable the observation of its dynamic tracking, including transport within cells, will provide tools for elucidation of presented hypotheses $[85,130]$.

Funding: This research received no external funding.

Conflicts of Interest: The authors declare no conflict of interest.

$\begin{array}{ll}\text { Abbreviations } \\ \text { CNS } & \text { Central nervous system } \\ \text { DMV } & \text { Dorsal motor nucleus of the vagus } \\ \text { EECs } & \text { Enteroendocrine cells } \\ \text { ENS } & \text { Enteric nervous system } \\ \text { GI } & \text { Gastrointestinal } \\ \text { IML } & \text { Intermediolateral cell column }\end{array}$




$\begin{array}{ll}\text { KYN } & \text { Kynurenine } \\ \text { LAG3 } & \text { Lymphocyte-activation gene } 3 \\ \text { LBs } & \text { Lewy bodies } \\ \text { LNs } & \text { Lewy neuritis } \\ \text { LP } & \text { Lewy pathology } \\ \text { LPS } & \text { Lipopolysaccharide } \\ \text { PANS } & \text { Peripheral autonomic nervous system } \\ \text { PFFs } & \text { Preformed fibrillar } \alpha \text {-synuclein assemblies } \\ \text { PD } & \text { Parkinson's disease } \\ \text { SCFAs } & \text { Short chain fatty acids } \\ \text { SIBO } & \text { Small intestinal overgrowth } \\ \text { SNpc } & \text { Substantia nigra pars compacta } \\ \text { TNTs } & \text { Tunneling nanotubes } \\ \text { VM } & \text { Ventral mesencephalic }\end{array}$

\section{References}

1. Kalia, L.V.; Lang, A.E. Parkinson's disease. Lancet 2015, 386, 896-912. [CrossRef]

2. Poirier, A.A.; Aubé, B.; Côté, M.; Morin, N.; Di Paolo, T.; Soulet, D. Gastrointestinal Dysfunctions in Parkinson's Disease: Symptoms and Treatments. Parkinsons Dis. 2016, 2016, 6762528. [CrossRef] [PubMed]

3. Stirpe, P.; Hoffman, M.; Badiali, D.; Colosimo, C. Constipation: An emerging risk factor for Parkinson's disease? Eur. J. Neurol. 2016, 23, 1606-1613. [CrossRef] [PubMed]

4. Cersosimo, M.G.; Benarroch, E.E. Pathological correlates of gastrointestinal dysfunction in Parkinson's disease. Neurobiol. Dis. 2012, 46, 559-564. [CrossRef] [PubMed]

5. Braak, H.; del Tredici, K.; Rüb, U.; de Vos, R.A.; Jansen Steur, E.N.; Braak, E. Staging of brain pathology related to sporadic Parkinson's disease. Neurobiol. Aging 2003, 24, 197-211. [CrossRef]

6. Saito, Y.; Shioya, A.; Sano, T.; Sumikura, H.; Murata, M.; Murayama, S. Lewy body pathology involves the olfactory cells in Parkinson's disease and related disorders. Mov. Disord. 2016, 31, 135-138. [CrossRef] [PubMed]

7. Wakabayashi, K.; Takahashi, H.; Takeda, S.; Ohama, E.; Ikuta, F. Parkinson's disease: The presence of Lewy bodies in Auerbach's and Meissner's plexuses. Acta Neuropathol. 1988, 76, 217-221. [CrossRef] [PubMed]

8. Del Tredici, K.; Hawkes, C.H.; Ghebremedhin, E.; Braak, H. Lewy pathology in the submandibular gland of individuals with incidental Lewy body disease and sporadic Parkinson's disease. Acta Neuropathol. 2010, 119, 703-713. [CrossRef] [PubMed]

9. Braak, H.; del Tredici, K. Invited Article: Nervous system pathology in sporadic Parkinson disease. Neurology 2008, 70, 1916-1925. [CrossRef] [PubMed]

10. Brundin, P.; Ma, J.; Kordower, J.H. How strong is the evidence that Parkinson's disease is a prion disorder? Curr. Opin. Neurol. 2016, 29, 459-466. [CrossRef] [PubMed]

11. Kordower, J.H.; Chu, Y.; Hauser, R.A.; Freeman, T.B.; Olanow, C.W. Lewy body-like pathology in long-term embryonic nigral transplants in Parkinson's disease. Nat. Med. 2008, 14, 504-506. [CrossRef] [PubMed]

12. Kordower, J.H.; Chu, Y.; Hauser, R.A.; Olanow, C.W.; Freeman, T.B. Transplanted dopaminergic neurons develop PD pathologic changes: A second case report. Mov. Disord. 2008, 23, 2303-2306. [CrossRef] [PubMed]

13. Li, J.Y.; Englund, E.; Holton, J.L.; Soulet, D.; Hagell, P.; Lees, A.J.; Lashley, T.; Quinn, N.P.; Rehncrona, S.; Björklund, A.; et al. Lewy bodies in grafted neurons in subjects with Parkinson's disease suggest host-to-graft disease propagation. Nat. Med. 2008, 14, 501-503. [CrossRef] [PubMed]

14. Bae, E.J.; Lee, H.J.; Lee, S.J. Cell Models to Study Cell-to-Cell Transmission of $\alpha$-Synuclein. Methods Mol. Biol. 2016, 1345, 291-298. [CrossRef] [PubMed]

15. Emmanouilidou, E.; Melachroinou, K.; Roumeliotis, T.; Garbis, S.D.; Ntzouni, M.; Margaritis, L.H.; Stefanis, L.; Vekrellis, K. Cell-produced alpha-synuclein is secreted in a calcium-dependent manner by exosomes and impacts neuronal survival. J. Neurosci. 2010, 30, 6838-6851. [CrossRef] [PubMed]

16. Lee, H.J.; Patel, S.; Lee, S.J. Intravesicular localization and exocytosis of alpha-synuclein and its aggregates. J. Neurosci. 2005, 25, 6016-6024. [CrossRef] [PubMed] 
17. Visanji, N.P.; Brooks, P.L.; Hazrati, L.N.; Lang, A.E. The prion hypothesis in Parkinson's disease: Braak to the future. Acta Neuropathol. Commun. 2013, 1, 2. [CrossRef] [PubMed]

18. Prymaczok, N.C.; Riek, R.; Gerez, J. More than a Rumor Spreads in Parkinson's Disease. Front. Hum. Neurosci. 2016, 10, 608. [CrossRef] [PubMed]

19. Jucker, M.; Walker, L.C. Propagation and spread of pathogenic protein assemblies in neurodegenerative diseases. Nat. Neurosci. 2018, 21, 1341-1349. [CrossRef] [PubMed]

20. Chen, Y.; Shao, Q.; Yuan, Y.H.; Chen, N.H. Prion-like propagation of $\alpha$-synuclein in the gut-brain axis. Brain Res. Bull. 2018, 140, 341-346. [CrossRef] [PubMed]

21. Mittal, R.; Debs, L.H.; Patel, A.P.; Nguyen, D.; Patel, K.; O'Connor, G.; Grati, M.; Mittal, J.; Yan, D.; Eshraghi, A.A.; et al. Neurotransmitters: The Critical Modulators Regulating Gut-Brain Axis. J. Cell. Physiol. 2017, 232, 2359-2372. [CrossRef] [PubMed]

22. Wang, Y.; Kasper, L.H. The role of microbiome in central nervous system disorders. Brain Behav. Immun. 2014, 38, 1-12. [CrossRef] [PubMed]

23. Felice, V.D.; Quigley, E.M.; Sullivan, A.M.; O'Keeffe, G.W.; O’Mahony, S.M. Microbiota-gut-brain signalling in Parkinson's disease: Implications for non-motor symptoms. Parkinsonism Relat. Disord. 2016, 27, 1-8. [CrossRef] [PubMed]

24. Calvani, R.; Picca, A.; Lo Monaco, M.R.; Landi, F.; Bernabei, R.; Marzetti, E. Of Microbes and Minds: A Narrative Review on the Second Brain Aging. Front. Med. 2018, 5, 53. [CrossRef] [PubMed]

25. Pan-Montojo, F.; Anichtchik, O.; Dening, Y.; Knels, L.; Pursche, S.; Jung, R.; Jackson, S.; Gille, G.; Spillantini, M.G.; Reichmann, H.; et al. Progression of Parkinson's disease pathology is reproduced by intragastric administration of rotenone in mice. PLoS ONE 2010, 5, e8762. [CrossRef] [PubMed]

26. Pan-Montojo, F.; Schwarz, M.; Winkler, C.; Arnhold, M.; O'Sullivan, G.A.; Pal, A.; Said, J.; Marsico, G.; Verbavatz, J.M.; Rodrigo-Angulo, M.; et al. Environmental toxins trigger PD-like progression via increased alpha-synuclein release from enteric neurons in mice. Sci. Rep. 2012, 2, 898. [CrossRef] [PubMed]

27. Noorian, A.R.; Rha, J.; Annerino, D.M.; Bernhard, D.; Taylor, G.M.; Greene, J.G. $\alpha$-Synuclein transgenic mice display age-related slowing of gastrointestinal motility associated with transgene expression in the vagal system. Neurobiol. Dis. 2012, 48, 9-19. [CrossRef] [PubMed]

28. Svensson, E.; Horváth-Puhó, E.; Thomsen, R.W.; Djurhuus, J.C.; Pedersen, L.; Borghammer, P.; Sørensen, H.T. Vagotomy and subsequent risk of Parkinson's disease. Ann. Neurol. 2015, 78, 522-529. [CrossRef] [PubMed]

29. Unger, M.M.; Spiegel, J.; Dillmann, K.U.; Grundmann, D.; Philippeit, H.; Bürmann, J.; Faßbender, K.; Schwiertz, A.; Schäfer, K.H. Short chain fatty acids and gut microbiota differ between patients with Parkinson's disease and age-matched controls. Parkinsonism Relat. Disord. 2016, 32, 66-72. [CrossRef] [PubMed]

30. Forsyth, C.B.; Shannon, K.M.; Kordower, J.H.; Voigt, R.M.; Shaikh, M.; Jaglin, J.A.; Estes, J.D.; Dodiya, H.B.; Keshavarzian, A. Increased intestinal permeability correlates with sigmoid mucosa $\alpha$-synuclein staining and endotoxin exposure markers in early Parkinson's disease. PLoS ONE 2011, 6, e28032. [CrossRef] [PubMed]

31. Keshavarzian, A.; Green, S.J.; Engen, P.A.; Voigt, R.M.; Naqib, A.; Forsyth, C.B.; Mutlu, E.; Shannon, K.M. Colonic bacterial composition in Parkinson's disease. Mov. Disord. 2015, 30, 1351-1360. [CrossRef] [PubMed]

32. Caputi, V.; Giron, M.C. Microbiome-Gut-Brain Axis and Toll-Like Receptors in Parkinson's Disease. Int. J. Mol. Sci. 2018, 19, 1689. [CrossRef] [PubMed]

33. Hasegawa, S.; Goto, S.; Tsuji, H.; Okuno, T.; Asahara, T.; Nomoto, K.; Shibata, A.; Fujisawa, Y.; Minato, T.; Okamoto, A.; et al. Intestinal Dysbiosis and Lowered Serum Lipopolysaccharide-Binding Protein in Parkinson's Disease. PLoS ONE 2015, 10, e0142164. [CrossRef] [PubMed]

34. Scheperjans, F.; Aho, V.; Pereira, P.A.; Koskinen, K.; Paulin, L.; Pekkonen, E.; Haapaniemi, E.; Kaakkola, S.; Eerola-Rautio, J.; Pohja, M.; et al. Gut microbiota are related to Parkinson's disease and clinical phenotype. Mov. Disord. 2015, 30, 350-358. [CrossRef] [PubMed]

35. Petrov, V.A.; Saltykova, I.V.; Zhukova, I.A.; Alifirova, V.M.; Zhukova, N.G.; Dorofeeva, Y.B.; Tyakht, A.V.; Kovarsky, B.A.; Alekseev, D.G.; Kostryukova, E.S.; et al. Analysis of Gut Microbiota in Patients with Parkinson's Disease. Bull. Exp. Biol. Med. 2017, 162, 734-737. [CrossRef] [PubMed]

36. Bedarf, J.R.; Hildebrand, F.; Coelho, L.P.; Sunagawa, S.; Bahram, M.; Goeser, F.; Bork, P.; Wüllner, U. Functional implications of microbial and viral gut metagenome changes in early stage L-DOPA-naïve Parkinson's disease patients. Genome Med. 2017, 9, 39. [CrossRef] [PubMed] 
37. Hill-Burns, E.M.; Debelius, J.W.; Morton, J.T.; Wissemann, W.T.; Lewis, M.R.; Wallen, Z.D.; Peddada, S.D.; Factor, S.A.; Molho, E.; Zabetian, C.P.; et al. Parkinson's disease and Parkinson's disease medications have distinct signatures of the gut microbiome. Mov. Disord. 2017, 32, 739-749. [CrossRef] [PubMed]

38. Tetz, G.; Brown, S.M.; Hao, Y.; Tetz, V. Parkinson's disease and bacteriophages as its overlooked contributors. Sci. Rep. 2018, 8, 10812. [CrossRef] [PubMed]

39. Gabrielli, M.; Bonazzi, P.; Scarpellini, E.; Bendia, E.; Lauritano, E.C.; Fasano, A.; Ceravolo, M.G.; Capecci, M.; Rita Bentivoglio, A.; Provinciali, L.; et al. Prevalence of small intestinal bacterial overgrowth in Parkinson's disease. Mov. Disord. 2011, 26, 889-892. [CrossRef] [PubMed]

40. Fasano, A.; Bove, F.; Gabrielli, M.; Petracca, M.; Zocco, M.A.; Ragazzoni, E.; Barbaro, F.; Piano, C.; Fortuna, S.; Tortora, A.; et al. The role of small intestinal bacterial overgrowth in Parkinson's disease. Mov. Disord. 2013, 28, 1241-1249. [CrossRef] [PubMed]

41. Tan, A.H.; Mahadeva, S.; Thalha, A.M.; Gibson, P.R.; Kiew, C.K.; Yeat, C.M.; Ng, S.W.; Ang, S.P.; Chow, S.K.; Tan, C.T.; et al. Small intestinal bacterial overgrowth in Parkinson's disease. Parkinsonism Relat. Disord. 2014, 20, 535-540. [CrossRef] [PubMed]

42. Cassani, E.; Barichella, M.; Cancello, R.; Cavanna, F.; Iorio, L.; Cereda, E.; Bolliri, C.; Zampella Maria, P.; Bianchi, F.; Cestaro, B.; et al. Increased urinary indoxyl sulfate (indican): New insights into gut dysbiosis in Parkinson's disease. Parkinsonism Relat. Disord. 2015, 21, 389-393. [CrossRef] [PubMed]

43. Gerhardt, S.; Mohajeri, M.H. Changes of Colonic Bacterial Composition in Parkinson's Disease and Other Neurodegenerative Diseases. Nutrients 2018, 10, 708. [CrossRef] [PubMed]

44. Yang, N.J.; Chiu, I.M. Bacterial Signaling to the Nervous System through Toxins and Metabolites. J. Mol. Biol. 2017, 429, 587-605. [CrossRef] [PubMed]

45. Morrison, D.J.; Preston, T. Formation of short chain fatty acids by the gut microbiota and their impact on human metabolism. Gut Microbes 2016, 7, 189-200. [CrossRef] [PubMed]

46. Clairembault, T.; Leclair-Visonneau, L.; Coron, E.; Bourreille, A.; Le Dily, S.; Vavasseur, F.; Heymann, M.F.; Neunlist, M.; Derkinderen, P. Structural alterations of the intestinal epithelial barrier in Parkinson's disease. Acta Neuropathol. Commun. 2015, 3, 12. [CrossRef] [PubMed]

47. Lionnet, A.; Leclair-Visonneau, L.; Neunlist, M.; Murayama, S.; Takao, M.; Adler, C.H.; Derkinderen, P.; Beach, T.G. Does Parkinson's disease start in the gut? Acta Neuropathol. 2018, 135, 1-12. [CrossRef] [PubMed]

48. Pituch, A.; Walkowiak, J.; Banaszkiewicz, A. Butyric acid in functional constipation. Prz. Gastroenterol. 2013, 8, 295-298. [CrossRef] [PubMed]

49. Ohira, H.; Tsutsui, W.; Fujioka, Y. Are Short Chain Fatty Acids in Gut Microbiota Defensive Players for Inflammation and Atherosclerosis? J. Atheroscler. Thromb. 2017, 24, 660-672. [CrossRef] [PubMed]

50. Engen, P.A.; Dodiya, H.B.; Naqib, A.; Forsyth, C.B.; Green, S.J.; Voigt, R.M.; Kordower, J.H.; Mutlu, E.A.; Shannon, K.M.; Keshavarzian, A. The Potential Role of Gut-Derived Inflammation in Multiple System Atrophy. J. Parkinsons Dis. 2017, 7, 331-346. [CrossRef] [PubMed]

51. Goldman, S.M.; Kamel, F.; Ross, G.W.; Jewell, S.A.; Marras, C.; Hoppin, J.A.; Umbach, D.M.; Bhudhikanok, G.S.; Meng, C.; Korell, M.; et al. Peptidoglycan recognition protein genes and risk of Parkinson's disease. Mov. Disord. 2014, 29, 1171-1180. [CrossRef] [PubMed]

52. Luan, H.; Liu, L.F.; Meng, N.; Tang, Z.; Chua, K.K.; Chen, L.L.; Song, J.X.; Mok, V.C.; Xie, L.X.; Li, M.; et al. LC-MS-based urinary metabolite signatures in idiopathic Parkinson's disease. J. Proteome Res. 2015, 14, 467-478. [CrossRef] [PubMed]

53. Morris, G.; Berk, M.; Carvalho, A.; Caso, J.R.; Sanz, Y.; Walder, K.; Maes, M. The Role of the Microbial Metabolites Including Tryptophan Catabolites and Short Chain Fatty Acids in the Pathophysiology of Immune-Inflammatory and Neuroimmune Disease. Mol. Neurobiol. 2017, 54, 4432-4451. [CrossRef] [PubMed]

54. Stolzenberg, E.; Berry, D.; Yang, D.; Lee, E.Y.; Kroemer, A.; Kaufman, S.; Wong, G.C.L.; Oppenheim, J.J.; Sen, S.; Fishbein, T.; et al. A Role for Neuronal Alpha-Synuclein in Gastrointestinal Immunity. J. Innate Immun. 2017, 9, 456-463. [CrossRef] [PubMed]

55. Braak, H.; de Vos, R.A.; Bohl, J.; del Tredici, K. Gastric alpha-synuclein immunoreactive inclusions in Meissner's and Auerbach's plexuses in cases staged for Parkinson's disease-related brain pathology. Neurosci. Lett. 2006, 396, 67-72. [CrossRef] [PubMed] 
56. Shannon, K.M.; Keshavarzian, A.; Dodiya, H.B.; Jakate, S.; Kordower, J.H. Is alpha-synuclein in the colon a biomarker for premotor Parkinson's disease? Evidence from 3 cases. Mov. Disord. 2012, 27, 716-719. [CrossRef] [PubMed]

57. Shannon, K.M.; Keshavarzian, A.; Mutlu, E.; Dodiya, H.B.; Daian, D.; Jaglin, J.A.; Kordower, J.H. $\alpha$-Synuclein in colonic submucosa in early untreated Parkinson's disease. Mov. Disord. 2012, 27, 709-715. [CrossRef] [PubMed]

58. Gold, A.; Turkalp, Z.T.; Munoz, D.G. Enteric alpha-synuclein expression is increased in Parkinson's disease but not Alzheimer's disease. Mov. Disord. 2013, 28, 237-240. [CrossRef] [PubMed]

59. Hilton, D.; Stephens, M.; Kirk, L.; Edwards, P.; Potter, R.; Zajicek, J.; Broughton, E.; Hagan, H.; Carroll, C. Accumulation of $\alpha$-synuclein in the bowel of patients in the pre-clinical phase of Parkinson's disease. Acta Neuropathol. 2014, 127, 235-241. [CrossRef] [PubMed]

60. Visanji, N.P.; Marras, C.; Kern, D.S.; Al Dakheel, A.; Gao, A.; Liu, L.W.; Lang, A.E.; Hazrati, L.N. Colonic mucosal a-synuclein lacks specificity as a biomarker for Parkinson disease. Neurology 2015, 84, 609-616. [CrossRef] [PubMed]

61. Lebouvier, T.; Neunlist, M.; Bruley des Varannes, S.; Coron, E.; Drouard, A.; N'Guyen, J.M.; Chaumette, T.; Tasselli, M.; Paillusson, S.; Flamand, M.; et al. Colonic biopsies to assess the neuropathology of Parkinson's disease and its relationship with symptoms. PLoS ONE 2010, 5, e12728. [CrossRef] [PubMed]

62. Pouclet, H.; Lebouvier, T.; Coron, E.; des Varannes, S.B.; Rouaud, T.; Roy, M.; Neunlist, M.; Derkinderen, P. A comparison between rectal and colonic biopsies to detect Lewy pathology in Parkinson's disease. Neurobiol. Dis. 2012, 45, 305-309. [CrossRef] [PubMed]

63. Corbillé, A.G.; Letournel, F.; Kordower, J.H.; Lee, J.; Shanes, E.; Neunlist, M.; Munoz, D.G.; Derkinderen, P.; Beach, T.G. Evaluation of alpha-synuclein immunohistochemical methods for the detection of Lewy-type synucleinopathy in gastrointestinal biopsies. Acta Neuropathol. Commun. 2016, 4, 35. [CrossRef] [PubMed]

64. Lebouvier, T.; Chaumette, T.; Damier, P.; Coron, E.; Touchefeu, Y.; Vrignaud, S.; Naveilhan, P.; Galmiche, J.P.; Bruley des Varannes, S.; Derkinderen, P.; et al. Pathological lesions in colonic biopsies during Parkinson's disease. Gut 2008, 57, 1741-1743. [CrossRef] [PubMed]

65. Beach, T.G.; Adler, C.H.; Sue, L.I.; Vedders, L.; Lue, L.; White Iii, C.L.; Akiyama, H.; Caviness, J.N.; Shill, H.A.; Sabbagh, M.N.; et al. Multi-organ distribution of phosphorylated alpha-synuclein histopathology in subjects with Lewy body disorders. Acta Neuropathol. 2010, 119, 689-702. [CrossRef] [PubMed]

66. Gelpi, E.; Navarro-Otano, J.; Tolosa, E.; Gaig, C.; Compta, Y.; Rey, M.J.; Martí, M.J.; Hernández, I.; Valldeoriola, F.; Reñé, R.; et al. Multiple organ involvement by alpha-synuclein pathology in Lewy body disorders. Mov. Disord. 2014, 29, 1010-1018. [CrossRef] [PubMed]

67. Stokholm, M.G.; Danielsen, E.H.; Hamilton-Dutoit, S.J.; Borghammer, P. Pathological $\alpha$-synuclein in gastrointestinal tissues from prodromal Parkinson disease patients. Ann. Neurol. 2016, 79, 940-949. [CrossRef] [PubMed]

68. Sánchez-Ferro, Á.; Rábano, A.; Catalán, M.J.; Rodríguez-Valcárcel, F.C.; Fernández Díez, S.; Herreros-Rodríguez, J.; García-Cobos, E.; Álvarez-Santullano, M.M.; López-Manzanares, L.; Mosqueira, A.J.; et al. In vivo gastric detection of $\alpha$-synuclein inclusions in Parkinson's disease. Mov. Disord. 2015, 30, 517-524. [CrossRef] [PubMed]

69. Bloch, A.; Probst, A.; Bissig, H.; Adams, H.; Tolnay, M. $\alpha$-synuclein pathology of the spinal and peripheral autonomic nervous system in neurologically unimpaired elderly subjects. Neuropathol. Appl. Neurobiol. 2006, 32, 284-295. [CrossRef] [PubMed]

70. Wakabayashi, K.; Takahashi, H.; Ohama, E.; Ikuta, F. Parkinson's disease: An immunohistochemical study of Lewy body-containing neurons in the enteric nervous system. Acta Neuropathol. 1990, 79, 581-583. [CrossRef] [PubMed]

71. Hopkins, D.A.; Bieger, D.; deVente, J.; Steinbusch, W.M. Vagal efferent projections: Viscerotopy, neurochemistry and effects of vagotomy. Prog. Brain Res. 1996, 107, 79-96. [PubMed]

72. Halliday, G.M.; Li, Y.W.; Blumbergs, P.C.; Joh, T.H.; Cotton, R.G.; Howe, P.R.; Blessing, W.W.; Geffen, L.B. Neuropathology of immunohistochemically identified brainstem neurons in Parkinson's disease. Ann. Neurol. 1990, 27, 373-385. [CrossRef] [PubMed]

73. Wakabayashi, K.; Toyoshima, Y.; Awamori, K.; Anezaki, T.; Yoshimoto, M.; Tsuji, S.; Takahashi, H. Restricted occurrence of Lewy bodies in the dorsal vagal nucleus in a patient with late-onset parkinsonism. J. Neurol. Sci. 1999, 165, 188-191. [CrossRef] 
74. Del Tredici, K.; Rüb, U.; de Vos, R.A.; Bohl, J.R.; Braak, H. Where does parkinson disease pathology begin in the brain? J. Neuropathol. Exp. Neurol. 2002, 61, 413-426. [CrossRef] [PubMed]

75. Braak, H.; Sastre, M.; Bohl, J.R.; de Vos, R.A.; del Tredici, K. Parkinson's disease: Lesions in dorsal horn layer I, involvement of parasympathetic and sympathetic pre- and postganglionic neurons. Acta Neuropathol. 2007, 113, 421-429. [CrossRef] [PubMed]

76. Böttner, M.; Zorenkov, D.; Hellwig, I.; Barrenschee, M.; Harde, J.; Fricke, T.; Deuschl, G.; Egberts, J.H.; Becker, T.; Fritscher-Ravens, A.; et al. Expression pattern and localization of alpha-synuclein in the human enteric nervous system. Neurobiol. Dis. 2012, 48, 474-480. [CrossRef] [PubMed]

77. Adler, C.H.; Dugger, B.N.; Hinni, M.L.; Lott, D.G.; Driver-Dunckley, E.; Hidalgo, J.; Henry-Watson, J.; Serrano, G.; Sue, L.I.; Nagel, T.; et al. Submandibular gland needle biopsy for the diagnosis of Parkinson disease. Neurology 2014, 82, 858-864. [CrossRef] [PubMed]

78. Beach, T.G.; Adler, C.H.; Dugger, B.N.; Serrano, G.; Hidalgo, J.; Henry-Watson, J.; Shill, H.A.; Sue, L.I.; Sabbagh, M.N.; Akiyama, H.; et al. Submandibular gland biopsy for the diagnosis of Parkinson disease. J. Neuropathol. Exp. Neurol. 2013, 72, 130-136. [CrossRef] [PubMed]

79. Hubbard, P.S.; Esiri, M.M.; Reading, M.; McShane, R.; Nagy, Z. $\alpha$-Synuclein pathology in the olfactory pathways of dementia patients. J. Anat. 2007, 211, 117-124. [CrossRef] [PubMed]

80. Beach, T.G.; White, C.L.; Hladik, C.L.; Sabbagh, M.N.; Connor, D.J.; Shill, H.A.; Sue, L.I.; Sasse, J.; Bachalakuri, J.; Henry-Watson, J.; et al. Olfactory bulb alpha-synucleinopathy has high specificity and sensitivity for Lewy body disorders. Acta Neuropathol. 2009, 117, 169-174. [CrossRef] [PubMed]

81. Doty, R.L. Olfaction in Parkinson's disease and related disorders. Neurobiol. Dis. 2012, 46, 527-552. [CrossRef] [PubMed]

82. Braak, H.; del Tredici, K. Neuropathological Staging of Brain Pathology in Sporadic Parkinson's disease: Separating the Wheat from the Chaff. J. Parkinsons Dis. 2017, 7, S71-S85. [CrossRef] [PubMed]

83. Braak, H.; Ghebremedhin, E.; Rüb, U.; Bratzke, H.; del Tredici, K. Stages in the development of Parkinson's disease-related pathology. Cell Tissue Res. 2004, 318, 121-134. [CrossRef] [PubMed]

84. Del Tredici, K.; Braak, H. Spinal cord lesions in sporadic Parkinson's disease. Acta Neuropathol. 2012, 124, 643-664. [CrossRef] [PubMed]

85. Borghammer, P. How does Parkinson's disease begin? Perspectives on neuroanatomical pathways, prions, and histology. Mov. Disord. 2018, 33, 48-57. [CrossRef] [PubMed]

86. Hawkes, C.H.; del Tredici, K.; Braak, H. Parkinson's disease: A dual-hit hypothesis. Neuropathol. Appl. Neurobiol. 2007, 33, 599-614. [CrossRef] [PubMed]

87. Gray, M.T.; Munoz, D.G.; Gray, D.A.; Schlossmacher, M.G.; Woulfe, J.M. Alpha-synuclein in the appendiceal mucosa of neurologically intact subjects. Mov. Disord. 2014, 29, 991-998. [CrossRef] [PubMed]

88. Liu, B.; Fang, F.; Pedersen, N.L.; Tillander, A.; Ludvigsson, J.F.; Ekbom, A.; Svenningsson, P.; Chen, H.; Wirdefeldt, K. Vagotomy and Parkinson disease: A Swedish register-based matched-cohort study. Neurology 2017, 88, 1996-2002. [CrossRef] [PubMed]

89. Kurowska, Z.; Englund, E.; Widner, H.; Lindvall, O.; Li, J.Y.; Brundin, P. Signs of degeneration in 12-22-year old grafts of mesencephalic dopamine neurons in patients with Parkinson's disease. J. Parkinsons Dis. 2011, 1, 83-92. [CrossRef] [PubMed]

90. Peelaerts, W.; Bousset, L.; Baekelandt, V.; Melki, R. $\alpha$-Synuclein strains and seeding in Parkinson's disease, incidental Lewy body disease, dementia with Lewy bodies and multiple system atrophy: Similarities and differences. Cell Tissue Res. 2018, 373, 195-212. [CrossRef] [PubMed]

91. Goldman, S.M. Environmental toxins and Parkinson's disease. Annu. Rev. Pharmacol. Toxicol. 2014, 54, 141-164. [CrossRef] [PubMed]

92. Phillips, R.J.; Walter, G.C.; Wilder, S.L.; Baronowsky, E.A.; Powley, T.L. $\alpha$-Synuclein-immunopositive myenteric neurons and vagal preganglionic terminals: Autonomic pathway implicated in Parkinson's disease? Neuroscience 2008, 153, 733-750. [CrossRef] [PubMed]

93. Ulusoy, A.; Phillips, R.J.; Helwig, M.; Klinkenberg, M.; Powley, T.L.; di Monte, D.A. Brain-to-stomach transfer of $\alpha$-synuclein via vagal preganglionic projections. Acta Neuropathol. 2017, 133, 381-393. [CrossRef] [PubMed] 
94. Kuo, Y.M.; Li, Z.; Jiao, Y.; Gaborit, N.; Pani, A.K.; Orrison, B.M.; Bruneau, B.G.; Giasson, B.I.; Smeyne, R.J.; Gershon, M.D.; et al. Extensive enteric nervous system abnormalities in mice transgenic for artificial chromosomes containing Parkinson disease-associated alpha-synuclein gene mutations precede central nervous system changes. Hum. Mol. Genet. 2010, 19, 1633-1650. [CrossRef] [PubMed]

95. Ubeda-Bañon, I.; Saiz-Sanchez, D.; de la Rosa-Prieto, C.; Mohedano-Moriano, A.; Fradejas, N.; Calvo, S.; Argandoña-Palacios, L.; Garcia-Muñozguren, S.; Martinez-Marcos, A. Staging of $\alpha$-synuclein in the olfactory bulb in a model of Parkinson's disease: Cell types involved. Mov. Disord. 2010, 25, 1701-1707. [CrossRef] [PubMed]

96. Liddle, R.A. Parkinson's disease from the gut. Brain Res. 2018, 1693, 201-206. [CrossRef] [PubMed]

97. Pellegrini, C.; Antonioli, L.; Colucci, R.; Blandizzi, C.; Fornai, M. Interplay among gut microbiota, intestinal mucosal barrier and enteric neuro-immune system: A common path to neurodegenerative diseases? Acta Neuropathol. 2018, 136, 345-361. [CrossRef] [PubMed]

98. Yang, X.; Qian, Y.; Xu, S.; Song, Y.; Xiao, Q. Longitudinal Analysis of Fecal Microbiome and Pathologic Processes in a Rotenone Induced Mice Model of Parkinson's Disease. Front. Aging Neurosci. 2017, 9, 441. [CrossRef] [PubMed]

99. Sampson, T.R.; Debelius, J.W.; Thron, T.; Janssen, S.; Shastri, G.G.; Ilhan, Z.E.; Challis, C.; Schretter, C.E.; Rocha, S.; Gradinaru, V.; et al. Gut Microbiota Regulate Motor Deficits and Neuroinflammation in a Model of Parkinson's Disease. Cell 2016, 167, 1469-1480. [CrossRef] [PubMed]

100. Chen, S.G.; Stribinskis, V.; Rane, M.J.; Demuth, D.R.; Gozal, E.; Roberts, A.M.; Jagadapillai, R.; Liu, R.; Choe, K.; Shivakumar, B.; et al. Exposure to the Functional Bacterial Amyloid Protein Curli Enhances

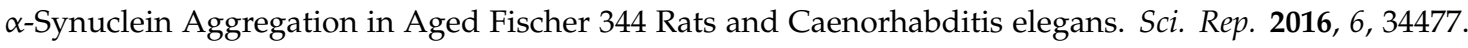
[CrossRef] [PubMed]

101. Kelly, L.P.; Carvey, P.M.; Keshavarzian, A.; Shannon, K.M.; Shaikh, M.; Bakay, R.A.; Kordower, J.H. Progression of intestinal permeability changes and alpha-synuclein expression in a mouse model of Parkinson's disease. Mov. Disord. 2014, 29, 999-1009. [CrossRef] [PubMed]

102. Arentsen, T.; Khalid, R.; Qian, Y.; Diaz Heijtz, R. Sex-dependent alterations in motor and anxiety-like behavior of aged bacterial peptidoglycan sensing molecule 2 knockout mice. Brain Behav. Immun. 2018, 67, 345-354. [CrossRef] [PubMed]

103. Quigley, E.M.M. Microbiota-Brain-Gut Axis and Neurodegenerative Diseases. Curr. Neurol. Neurosci. Rep. 2017, 17, 94. [CrossRef] [PubMed]

104. Kim, N.; Yun, M.; Oh, Y.J.; Choi, H.J. Mind-altering with the gut: Modulation of the gut-brain axis with probiotics. J. Microbiol. 2018, 56, 172-182. [CrossRef] [PubMed]

105. Breid, S.; Bernis, M.E.; Babila, J.T.; Garza, M.C.; Wille, H.; Tamgüney, G. Neuroinvasion of $\alpha$-Synuclein Prionoids after Intraperitoneal and Intraglossal Inoculation. J. Virol. 2016, 90, 9182-9193. [CrossRef] [PubMed]

106. Lee, H.J.; Suk, J.E.; Lee, K.W.; Park, S.H.; Blumbergs, P.C.; Gai, W.P.; Lee, S.J. Transmission of Synucleinopathies in the Enteric Nervous System of A53T $\alpha$-Synuclein Transgenic Mice. Exp. Neurobiol. 2011, 20, 181-188. [CrossRef] [PubMed]

107. Holmqvist, S.; Chutna, O.; Bousset, L.; Aldrin-Kirk, P.; Li, W.; Björklund, T.; Wang, Z.Y.; Roybon, L.; Melki, R.; Li, J.Y. Direct evidence of Parkinson pathology spread from the gastrointestinal tract to the brain in rats. Acta Neuropathol. 2014, 128, 805-820. [CrossRef] [PubMed]

108. Sacino, A.N.; Brooks, M.; Thomas, M.A.; McKinney, A.B.; Lee, S.; Regenhardt, R.W.; McGarvey, N.H.; Ayers, J.I.; Notterpek, L.; Borchelt, D.R.; et al. Intramuscular injection of $\alpha$-synuclein induces CNS $\alpha$-synuclein pathology and a rapid-onset motor phenotype in transgenic mice. Proc. Natl. Acad. Sci. USA 2014, 111, 10732-10737. [CrossRef] [PubMed]

109. Rey, N.L.; Steiner, J.A.; Maroof, N.; Luk, K.C.; Madaj, Z.; Trojanowski, J.Q.; Lee, V.M.; Brundin, P. Widespread transneuronal propagation of $\alpha$-synucleinopathy triggered in olfactory bulb mimics prodromal Parkinson's disease. J. Exp. Med. 2016, 213, 1759-1778. [CrossRef] [PubMed]

110. Koller, E.J.; Brooks, M.M.; Golde, T.E.; Giasson, B.I.; Chakrabarty, P. Inflammatory pre-conditioning restricts the seeded induction of $\alpha$-synuclein pathology in wild type mice. Mol. Neurodegener. 2017, 12, 1. [CrossRef] [PubMed] 
111. Sacino, A.N.; Brooks, M.; McKinney, A.B.; Thomas, M.A.; Shaw, G.; Golde, T.E.; Giasson, B.I. Brain injection of $\alpha$-synuclein induces multiple proteinopathies, gliosis, and a neuronal injury marker. J. Neurosci. 2014, 34, 12368-12378. [CrossRef] [PubMed]

112. Masuda-Suzukake, M.; Nonaka, T.; Hosokawa, M.; Oikawa, T.; Arai, T.; Akiyama, H.; Mann, D.M.; Hasegawa, M. Prion-like spreading of pathological $\alpha$-synuclein in brain. Brain 2013, 136, 1128-1138. [CrossRef] [PubMed]

113. Peelaerts, W.; Bousset, L.; van der Perren, A.; Moskalyuk, A.; Pulizzi, R.; Giugliano, M.; van den Haute, C.; Melki, R.; Baekelandt, V. $\alpha$-Synuclein strains cause distinct synucleinopathies after local and systemic administration. Nature 2015, 522, 340-344. [CrossRef] [PubMed]

114. Abdelmotilib, H.; Maltbie, T.; Delic, V.; Liu, Z.; Hu, X.; Fraser, K.B.; Moehle, M.S.; Stoyka, L.; Anabtawi, N.; Krendelchtchikova, V.; et al. $\alpha$-Synuclein fibril-induced inclusion spread in rats and mice correlates with dopaminergic Neurodegeneration. Neurobiol. Dis. 2017, 105, 84-98. [CrossRef] [PubMed]

115. Mao, X.; Ou, M.T.; Karuppagounder, S.S.; Kam, T.I.; Yin, X.; Xiong, Y.; Ge, P.; Umanah, G.E.; Brahmachari, S.; Shin, J.H.; et al. Pathological $\alpha$-synuclein transmission initiated by binding lymphocyte-activation gene 3. Science 2016, 353, aah3374. [CrossRef] [PubMed]

116. Luk, K.C.; Kehm, V.M.; Zhang, B.; O’Brien, P.; Trojanowski, J.Q.; Lee, V.M. Intracerebral inoculation of pathological $\alpha$-synuclein initiates a rapidly progressive neurodegenerative $\alpha$-synucleinopathy in mice. J. Exp. Med. 2012, 209, 975-986. [CrossRef] [PubMed]

117. Sargent, D.; Verchère, J.; Lazizzera, C.; Gaillard, D.; Lakhdar, L.; Streichenberger, N.; Morignat, E.; Bétemps, D.; Baron, T. 'Prion-like' propagation of the synucleinopathy of M83 transgenic mice depends on the mouse genotype and type of inoculum. J. Neurochem. 2017, 143, 126-135. [CrossRef] [PubMed]

118. Watts, J.C.; Giles, K.; Oehler, A.; Middleton, L.; Dexter, D.T.; Gentleman, S.M.; DeArmond, S.J.; Prusiner, S.B. Transmission of multiple system atrophy prions to transgenic mice. Proc. Natl. Acad. Sci. USA 2013, 110, 19555-19560. [CrossRef] [PubMed]

119. Mougenot, A.L.; Nicot, S.; Bencsik, A.; Morignat, E.; Verchère, J.; Lakhdar, L.; Legastelois, S.; Baron, T. Prion-like acceleration of a synucleinopathy in a transgenic mouse model. Neurobiol. Aging 2012, 33, 2225-2228. [CrossRef] [PubMed]

120. Recasens, A.; Dehay, B.; Bové, J.; Carballo-Carbajal, I.; Dovero, S.; Pérez-Villalba, A.; Fernagut, P.O.; Blesa, J.; Parent, A.; Perier, C.; et al. Lewy body extracts from Parkinson disease brains trigger $\alpha$-synuclein pathology and neurodegeneration in mice and monkeys. Ann. Neurol. 2014, 75, 351-362. [CrossRef] [PubMed]

121. Ulusoy, A.; Rusconi, R.; Pérez-Revuelta, B.I.; Musgrove, R.E.; Helwig, M.; Winzen-Reichert, B.; di Monte, D.A. Caudo-rostral brain spreading of $\alpha$-synuclein through vagal connections. EMBO Mol. Med. 2013, 5, 1119-1127. [CrossRef] [PubMed]

122. Angot, E.; Steiner, J.A.; Lema Tomé, C.M.; Ekström, P.; Mattsson, B.; Björklund, A.; Brundin, P. $\alpha$-synuclein cell-to-cell transfer and seeding in grafted dopaminergic neurons in vivo. PLoS ONE 2012, 7, e39465. [CrossRef] [PubMed]

123. Desplats, P.; Lee, H.J.; Bae, E.J.; Patrick, C.; Rockenstein, E.; Crews, L.; Spencer, B.; Masliah, E.; Lee, S.J. Inclusion formation and neuronal cell death through neuron-to-neuron transmission of $\alpha$-synuclein. Proc. Natl. Acad. Sci. USA 2009, 106, 13010-13015. [CrossRef] [PubMed]

124. Chandra, R.; Hiniker, A.; Kuo, Y.M.; Nussbaum, R.L.; Liddle, R.A. $\alpha$-Synuclein in gut endocrine cells and its implications for Parkinson's disease. JCI Insight 2017, 2, 92295. [CrossRef] [PubMed]

125. Kalaitzakis, M.E.; Graeber, M.B.; Gentleman, S.M.; Pearce, R.K. The dorsal motor nucleus of the vagus is not an obligatory trigger site of Parkinson's disease: A critical analysis of $\alpha$-synuclein staging. Neuropathol. Appl. Neurobiol. 2008, 34, 284-295. [CrossRef] [PubMed]

126. Attems, J.; Jellinger, K.A. The dorsal motor nucleus of the vagus is not an obligatory trigger site of Parkinson's disease. Neuropathol. Appl. Neurobiol. 2008, 34, 466-467. [CrossRef] [PubMed]

127. Fumimura, Y.; Ikemura, M.; Saito, Y.; Sengoku, R.; Kanemaru, K.; Sawabe, M.; Arai, T.; Ito, G.; Iwatsubo, T.; Fukayama, M.; et al. Analysis of the adrenal gland is useful for evaluating pathology of the peripheral autonomic nervous system in Lewy body disease. J. Neuropathol. Exp. Neurol. 2007, 66, 354-362. [CrossRef] [PubMed]

128. Tysnes, O.B.; Kenborg, L.; Herlofson, K.; Steding-Jessen, M.; Horn, A.; Olsen, J.H.; Reichmann, H. Does vagotomy reduce the risk of Parkinson's disease? Ann. Neurol. 2015, 78, 1011-1012. [CrossRef] [PubMed] 
129. Recasens, A.; Carballo-Carbajal, I.; Parent, A.; Bové, J.; Gelpi, E.; Tolosa, E.; Vila, M. Lack of pathogenic potential of peripheral $\alpha$-synuclein aggregates from Parkinson's disease patients. Acta Neuropathol. Commun. 2018, 6, 8. [CrossRef] [PubMed]

130. Rietdijk, C.D.; Perez-Pardo, P.; Garssen, J.; van Wezel, R.J.; Kraneveld, A.D. Exploring Braak's Hypothesis of Parkinson's Disease. Front. Neurol. 2017, 8, 37. [CrossRef] [PubMed] 